\title{
A History of DiAmOND SOURCES IN AFRICA: PART I
}

By A. J. A. (Bram) Janse

For more than 100 years, Africa has produced large cornmercial quantities of diamonds and important individual stones. The earliest official finds were made from approximately 1867 onward, in sands and gravels of the Orange and Vaal Rivers in South Africa. Subsequently, diamonds were found in "hard rock" kimberlites and, most recently, in off-shore deposits along the western coast of South Africa and Namibia. Important discoveries have been made in many other African countries. Angola, Botswana, Central African Republic, Ghona, Namibin, and Zaire have now joined South Africa as being among the top 10 diamond-producing countries worldwide, Part I of this twopart series examines the fascinating history of these numerous discoveries in southern and central Africa from the 19 th century to the present. Part II will look at eastern and western Africa, as well as the history of diamond prospecting, mining, and production on the African continent.

\footnotetext{
ABOUT THE AUTHOR

Dr. Janse, president of Archon Exploration Pty Ltd. (Perth, Australia) and director of KWG Resources (Montreal, Canada), has 37 years of experience in diamond exploration.

Please see Acknowledgments at end of article. Gems \& Gemology, Vol. 31, No. 4, 1995, pp. 228-255 (01996 Gemological Institute of America
}

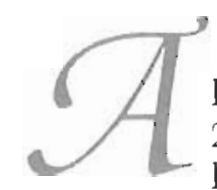

Ithough diamonds have been known for more than 2,000 years, with the earliest discoveries in India, large-scale mining and distribution date only from the late 1860s and the first finds in Africa. For almost a century, Africa-and especially South Africa-dominated diamond production, representing more than $98 \%$ of world output from 1889 to 1959 . Many of the most famous stones ever to enter the gem market originated from these African deposits. In addition, much of our current knowledge about diamond occurrences, exploration, and mining comes from the African diamond fields. And the history of these discoveries is among the richest in the archives of gemology.

The first reliable records of diamond finds in Africa date from the late 1860s ("Diamonds are trumps," April 18, 1867). These followed the earlier finds in India several centuries B.C. (recorded in Arthasastra and Ratnapariska Sanskrit texts, as reported in Legrand, 1984); Borneo in the 10th century A.D. (Legrand, 1984); Brazil in the 1720s (Sarmento, 1735; Bruton, $1978^{\star}$ ); Russia in the 1830s (Rose, 1837, pp. 352-374; Webster, 1975); the United States in the 1840s (Shepard, 1846; Kunz, 1892; Sinkankas, 1976); and Australia in the 1850 s (Hargraves, 1851; Atkinson et al., 1990). In most of these earlier instances, the diamonds were mere mineralogical curiosities, found as occasional by-products in the recovery of gold from sands and gravels in stream beds. Through the ages, production from India and Borneo reached Europe only as a trickle of large (over one carat) stones that were used mainly as adornments for sovereigns and their consorts, with smaller stones used for engraving and cutting tools. The Brazilian deposits provided a steady supply of small stones after 1730 (Lenzen, 1970), but large quantities of stones of significant size (including many $15 \mathrm{ct}$ and above) came only with the exploitation of the South African diamond fields from 1870 onwards (figure 1). In general, this sudden increase in supply coincided with the new wealth generated by the Industrial 
Figure 1. Alrica was the dominant source in the world diamond market for almost a hundred years after the first pieces of rough were reported in

South Africa in the 1860 s.

This suite of jewelry, designed by Gianmaria Buccellati, was fashioned

from predominantly

African rough collected over many years. The dia-

monds weigh a total of 344.11 carats. Courtesy of Buccellati of Beverly Hills, California; photo (C) Harold e) Erica Van Pelt.

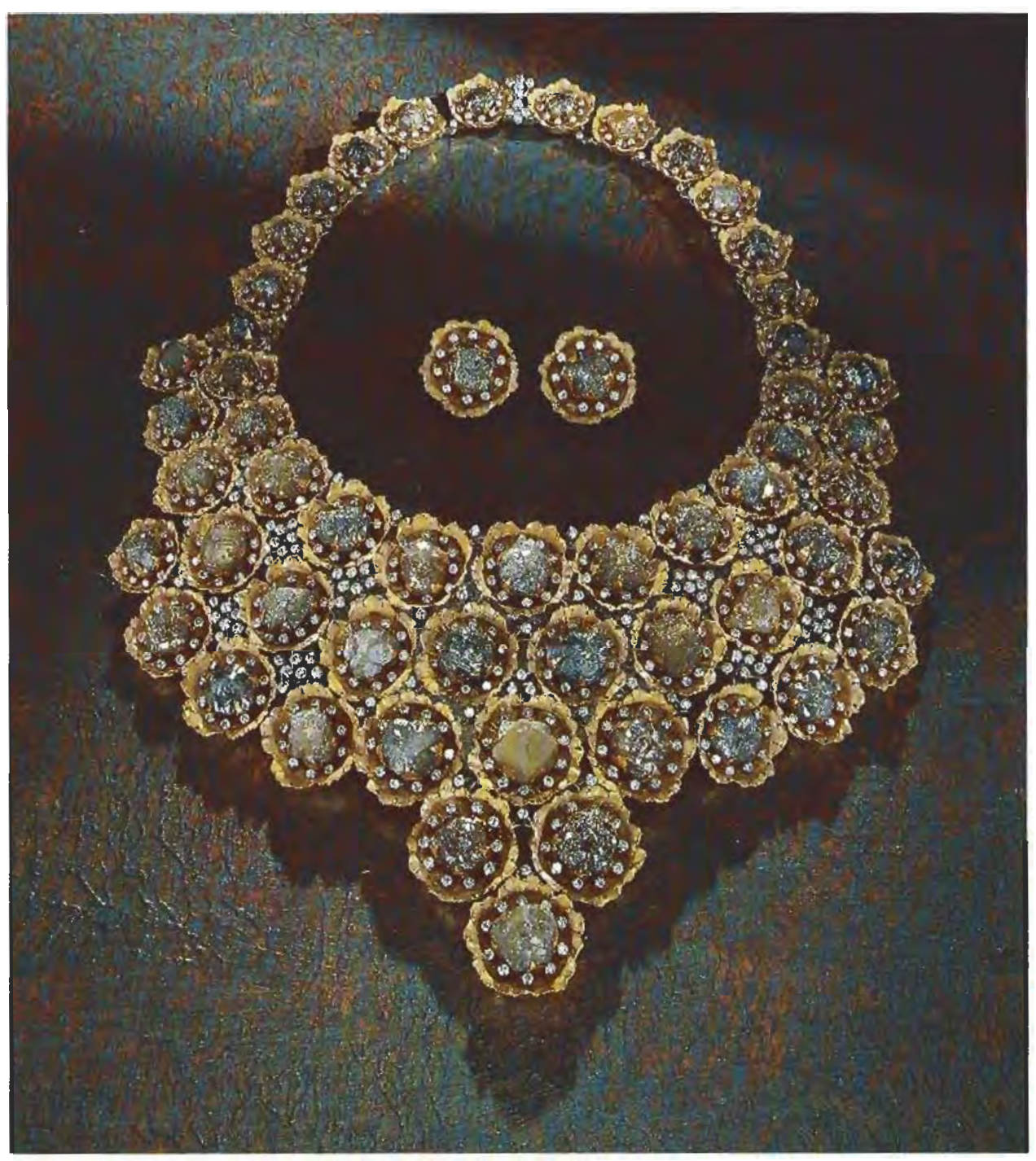

Revolution and the attendant increased demand for luxury goods by a broader range of consumers.

This article reviews the history of the major discoveries of alluvial diamonds and kimberlite pipes throughout the African continent, from the earliestin February 1867-near Kimberley, in South Africa, to the most recent discovery-in 1990-in the Sahara Desert, in Algeria (figure 2). The stories of the early diamond discoveries have been told many times, but many have become distorted and bowdlerized in the retelling. As much as possible, the information provided here has been culled from original sources farchival issues of periodicals and photocopies or

\footnotetext{
* Wherever two references are quoted with widely different years, the first reference indicates the earliest record that I have found, whereas the second reference is the more accessible and comprehensive. Note that they sometimes differ in detail and interpretation.
}

excerpts of original documents) or recollections of people directly involved in the events described. Please keep in mind that the quality of reporting in 19th-century periodicals is often not as high as in recent ones, in that there was less opportunity for onthe-spot investigation. As a result, much of the evidence was based on hearsay. Likewise, personal recollections often contain incorrect information caused by wishful thinking and faulty memory. There are several other interesting stories that could have been told, but they were omitted because they could not be substantiated.

The following is a country-by-country account (basically, from south to north and from east to west) of the progression of major diamond discoveries and exploitation in Africa. Part I surveys the important diamond-producing countries in southern and central Africa. Part II, to be published in an upcoming issue 


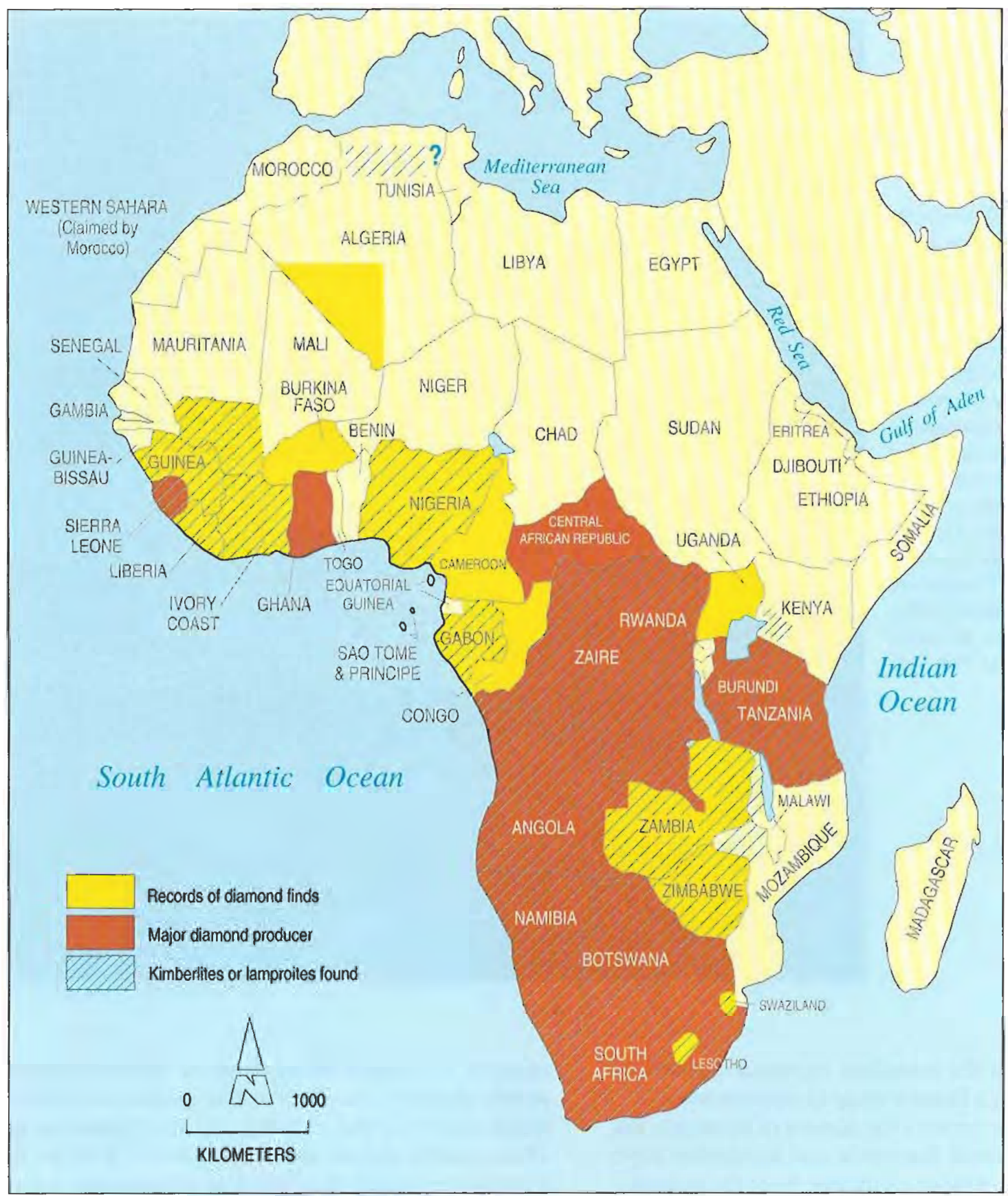

Figure 2. This map of Africa shows the countries in which diamonds and/or kimberlite or lamproite pipes have been found, highlighting those that are major diamond producers.

of Gems ef Gemology, will cover eastern and western Africa, and will provide a historical perspective on the techniques of prospecting and discovery, the development of mining methods, the recovery of diamonds, and the people involved in these activities. Part II will also discuss those countries in which only sporadic occurrences of diamonds and/or pipes have been found, or for which only unsubstantiated accounts have been published (Burkina Faso, Cam- eroon, Congo, Gabon, Kenya, Malawi, Mozambique, Nigeria, Uganda, and Zambia).

\section{SOUTH AFRICA}

South Africa is the most significant diamond-producing country on the African continent. The modern diamond industry was born here, and within five years after the initial discovery of alluvial diamonds, large quantities were being recovered from "hard 
rock" kimberlite sources. In fact, South Africa is considered the type locality for the occurrence of diamonds in igneous host rocks, such as kimberlite pipes, which were first discovered there in 1869 and recognized as such in 1872. The methods and special equipment now used worldwide for the recovery of diamonds were developed here.

Diamond production from kimberlite pipes around Kimberley exceeded one million carats within the first year of exploitation by local miners ("diggers" ${ }^{\prime \prime}$. The largest diamond ever found, the Cullinan $(3,106$ metric carats $)$, and many other very large diamonds were found in South Africa. This country has been a steady producer of several millions of carats annually up to the present, and important new discoveries are still being made.

The First Alluvial Diggings. Although a few diamonds were allegedly found earlier (Balfour, 1992; Liddicoat, 1993), the first officially recorded diamond on the African continent was found in the southern hemisphere's summer of $1866 / 1867$, either as early as December 1866 or as late as February 1867 (Robertson; 1974*). This stone, which weighed 21.25 old carats, " * was subsequently cut into a $10.73 \mathrm{ct}$ brilliant and named the Eureka (figure 3).

This stone was found on a farm named De Kalk, in lime-cemented gravels of a terrace along the southern banks of the Orange River, which at that time formed the boundary between the Cape Colony and the Orange Free State (figure 4). However, there are several different versions of its discovery.

The earliest public reports appeared in the Colesberg Advertiser ("The wonderful South African diamond," April 9, 1867) and two Cape Town newspapers, the English Cape Argus ("Diamonds are trumps," April 18, 1867) and the Dutch Het Volksblad ("Gerucht over een diamant . . .," April 18, 18671, which picked up the report from the Colesberg Advertiser. Het Volksblad ("Een Kaapsche diamant," April 30, 1867) carried the story that an experienced diamond cutter from Holland, Louis Hond, on request of Colonial Secretary Richard Southey, had identified a pebble "found by a Mr. $\mathrm{O}^{\prime}$ Reilly somewhere along the Orange River" as a

"A photograph of the first diamond in Robertson's book fopposite p. 64) shows a label with the date 7th February, 1867, written by Chalmers. I think that this may be the date of Van Niekerk's visit to the lacobs homestead.

** The old carat was slightly larger than the metric carat, which was officially adopted by De Beers in 1920 (De Beers Annual Report for 1988) and by South Africa in 1923 (Williams, 1932).

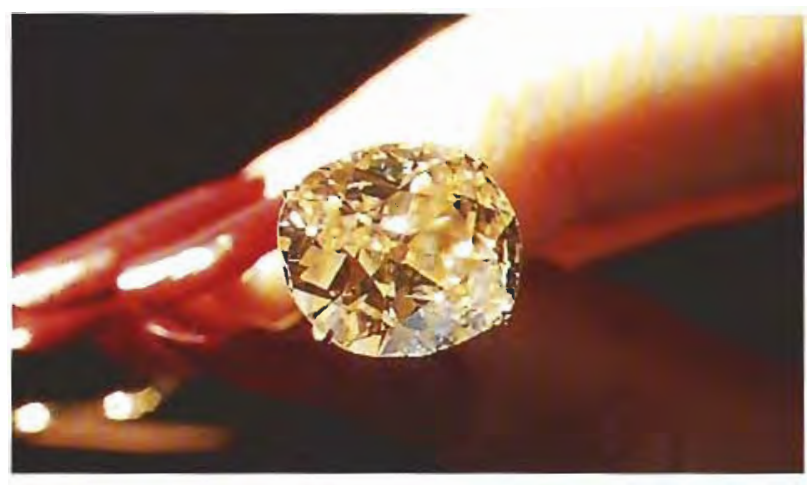

Figure 3. The 10.73 ct yellow diamond known as the Eurek a was reportedly faceted from the earliest recorded diamond in Africa, found in late 1866 or early 1867 on De Kalk farm near the Orange River. Photo courtesy of De Beers.

genuine diamond of $21.3 \mathrm{ct}$. (It remains unexplained why an experienced diamond cutter, such as Louis Hond, would have moved from Holland to Cape Town before it became known that diamonds were actually found in South Africa. Perhaps the knowledge of earlier diamond finds [see Balfour, 1992] was more widespread than has been reported, but this cannot be substantiated.) The actual location of the discovery was first mentioned in the Colesberg Advertiser ("Diamond mining," July 16, 1867) as a farm named "De Kalk." That article stated that Mr. Hond and his partner (a Belgian named Mons) were prospecting there and had found more diamonds.

The Colesberg Advertiser ("Nelly Jacobs . . .," July 30, 1867) and the London Joumal of the Society of Arts ("Precious stone . ..," October 4, 1867)--as well as a memorandum dated June 23, 1868, from Hopetown magistrate William B. Chalmers (cited in Weakley, 1869, and Robertson, 1974)-refer to the finder as a little girl, daughter of a poor Boer farmer named Daniel Jacobs, who lived on De Kalk farm. The Colesberg Advertiser even invented a name for the girl, "Little Nelly," but from Robertson (1974) we now know that she was called Fredrika (shortened to Riekie-pronounced "reekee" in Dutch/Afrikaans). The Cape Argus ("Twenty diamonds found . . .," October 31, 1868) published a map showing the location of the De Kalk farm, situated in Hopetown district along the left bank of the Orange River, about 30 $\mathrm{km}$ (18 miles) upstream from where it joined with the Vaal River.

The Chalmers memorandum describes the diamond as a pretty, white stone, a plaything of the little girl, which attracted the attention of a neighbor, 


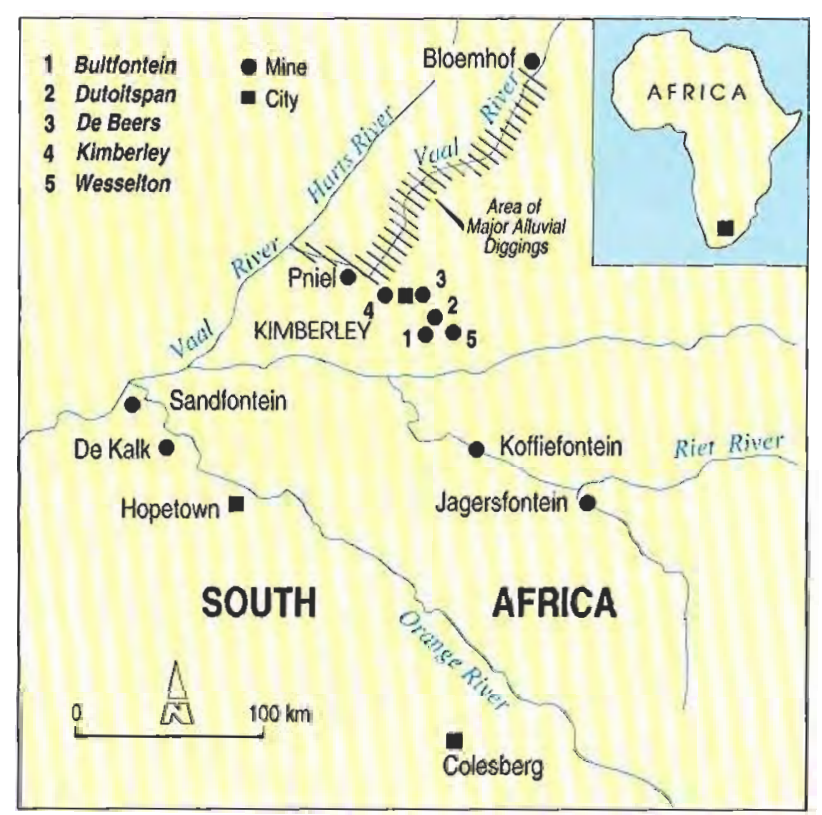

Figure 4. The first diamonds reported-and, subsequently, most of the major mines-in South Africa were located in the area between the Orange and Vaal Rivers. Note that the Kimberleyarea mines are shown here in relative position, not precise to scale, because they were clustered in such a small area.

Schalk Van Niekerk, when he was visiting in February 1867. * He offered to buy it, but Mrs. Jacobs scoffed at the idea of selling a mere pebble and gave it to him /Chalmers' account does not say what the little girl thought of this). Chalmers states that "Van Niekerk was a very shrewd man with an enquiring turn of mind" and credits him with "bringing to light the existence of diamonds along the Orange River." Van Niekerk gave the pebble to a local trader/hunter, John O'Reilly, to take it to Hopetown to see if it was worth anything, as he thought that it was a diamond. O'Reilly showed it to several people in Hopetown, including Chalmers, who all laughed at the idea that the pebble might be a diamond. Nevertheless, Chalmers says he advised O'Reilly to send it to Dr. Atherstone, a physician and self-taught geologist/ mineralogist living in Grahamstown.

\footnotetext{
*It is strange that Chalmers and Atherstone described the Jacobs/Van Niekerk dianond as a white stone. Hond, in his evaluation in Capetown, mentioned that it had a small yellow spot in one corner ("een geel vlekje," in "Een Kaapsche diamant," April 30, 1867). Garrard's certificate said "slightly colored" without stating which color (most dianonds from South Africa liave a faint yellow hue), whereas the Eureka is distinctly yellow.
}

Subsequently, Chalmers wrote that O'Reilly then went on to Colesberg where the town clerk, Lorenzo Boyes, sent the stone to Dr. Atherstone by letter, dated March 12, 1867 (see Chalmers' letter of January 20, 1969, cited in Robertson, 1974). Atherstone immediately responded that it was a diamond of $21.25 \mathrm{ct}$, worth $\$ 500$, and that he would like to send it to Colonial Secretary Southey in Cape Town (Atherstone, 1869). "* On April 16 or 17, Southey showed the stone to Ernest Héritte, the French consul, and the above-mentioned Louis Hond, both of whom confirmed Atherstone's assertions ("Diamonds are trumps," April 18, 1867). On April 19, the stone was sent by a steamer named the Celt to London for final verification by Garrard and Co., the Crown Jewellers. On July 12, 1867, Southey received a copy of the certificate that Garrard had issued the preceding month (June 8), which stated that it was a genuine diamond of good quality, slight-

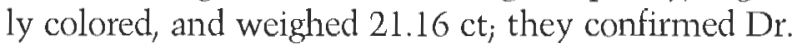
Atherstone's value of $£ 500$ (Garrard's certificate in Robertson, 1974). A replica of the stone was exhibited at the Paris Exhibition later in 1867. The diamond was subsequently purchased for $£ 500$ by Sir Philip Wodehouse, governor of the Cape Colony.

Chalmers' story of the find (little girl Jacobs, children playing with pebbles, Van Niekerk's interest, etc.) was quoted in the influential lecture on the discovery of diamonds in South Africa given by Professor James Tennant at the Society of Arts on November 23, 1870 (Tennant, 1870). Most early writers and, recently, Bruton (1978) follow Tennant's account.

In 1872, O'Reilly gave a different version of the find to Richard Murray, editor of the Diamond Fields Advertiser (published in the tent town then called De Beers New Rush, later renamed the city of Kimberley). O'Reilly said that while visiting Van Niekerk in March 1867, he saw Van Niekerk's little girl playing with some bright pebbles. He offered to buy a particularly shiny one, but Van Niekerk gave it to him on the understanding that if it was worth something they would share equally (Murray, 1873). The rest of the story is as told by Chalmers.

\footnotetext{
"The date on the letter from Boyes is reported in Atherstone, 1869. Atherstone's reply to Boyes was received in Colesberg on April 8. Atherstone determined the specific gravity of the stone, its hardness (it did scratch glass and was not scratched by a hardened steel file), its weight in carats, and its value (probably from the book by Jeffries, 1750, which includes a manual for establishing the value of a diamond from its weight and dinnensions). It was a remarkable effort for a self-taught mineralogist who had never before evaluated a diamond.
} 
In a petition to then-governor of the Cape Colony Sir Henry Barkly, filed January 10, 1872, at De Beers New Rush, O'Reilly claimed to have found (or at least recognized) the first diamond identified in South Africa. Again, he referred to a March 1867 visit to Van Niekerk, but in this account (reproduced in Robertson, 1974, pp. 73-74), he claimed to have picked out the diamond from among Van Niekerk's collection of stones. He offered to buy it, but Van Niekerk gave it to him, saying it belonged to "Daniel Jacobs' little Bushman boy." In an 1876 account, it was in the hands of a little Griqua servant boy who was minding the children (Matthews, 1878). In 1894, O'Reilly changed the little Griqua boy to a little Hottentot boy. In all of these accounts, the rest of the story is as told above.

O'Reilly's claim that he was the first to recognize the pebble's potential was so successful that the first book on the diamond fields (Reunert, 1893), and the most authoritative textbook on gemstones of that era (Bauer, 1896), gave O'Reilly the credit "for establishing the occurrence of diamonds in South Africa." Both publications called the first stone the "O'Reilly Diamond."

An account by a nephew of Van Niekerk given to George Beet in Kimberley states that it was Erasmus Jacobs (figure 5), second son of Daniel Jacobs of De Kalk farm, who found the first diamond (Beet and Terpend, 1917). John Noble, who visited De Kalk, also describes the finder as a young son of Daniel Jacobs, and this version was adopted by Williams (1905). In a swom affidavit, dated August 9, 1932, Erasmus Jacobs stated that he picked up a bright pebble near the dam on his father's farm, De Kalk, in the summer of 1866 when he was 15 years old (in Robertson, 1974). A Hottentot was standing by but had nothing to do with the discovery. Erasmus gave the stone to his little sister (Riekie). When Van Nickerk was visiting a month or two later, Erasmus and his brother and two sisters were playing games with some pebbles, including the bright one. Van Niekerk acquired it and then passed it on to O'Reilly, who took it to Hopetown and Colesberg.

This account ties up everything very neatly-too neatly, perhaps. The native servant is there (Hottentot, Griqua, or Bushman), but is dismissed as irrelevant; the little girl is there, but she got the stone from Erasmus; and O'Reilly is just the courier. Robertson (1974) commented that the information in the affidavit might have been obtained by "leading questions," that is, by putting words into Erasmus' mouth. Nevertheless, Van Niekerk gets the credit for thinking that the bright pebble might be a diamond.
But how did Van Niekerk get that idea? It may have come from a legend among the Boers that diamonds were collected by Bushmen along the Orange and Vaal Rivers (Dunn, 1871). There are also indications that Van Niekerk had found diamonds even before he recognized the Jacobs diamond "Jacobs' diamond ...," June 4, 1867; "Nelly Jacobs ...,", July $30,1867)$. In the mid-1860s, the government land surveyor, Von Ludwig, often stayed at Van Niekerk's house and the two discussed minerals. When he finished his survey of farms along the Orange River, Von Ludwig gave Van Niekerk a book on gemstones (Beet and Terpend, 1917).

Regardless of who actually found the first stone, it created a mild stir of interest among the Boers (pasturalists of mainly Dutch ancestry) and the Griquas shepherds of mixed Hottentot/Bushman/Bantu ancestry) living in the general area of the Orange and

Figure 5. Erasmus Jacobs has been credited with finding the first officially recorded diamond on the African continent, on his family's farm, De Kalk, in 1866. This photo was taken around 1907.

Courtesy of De Beers.

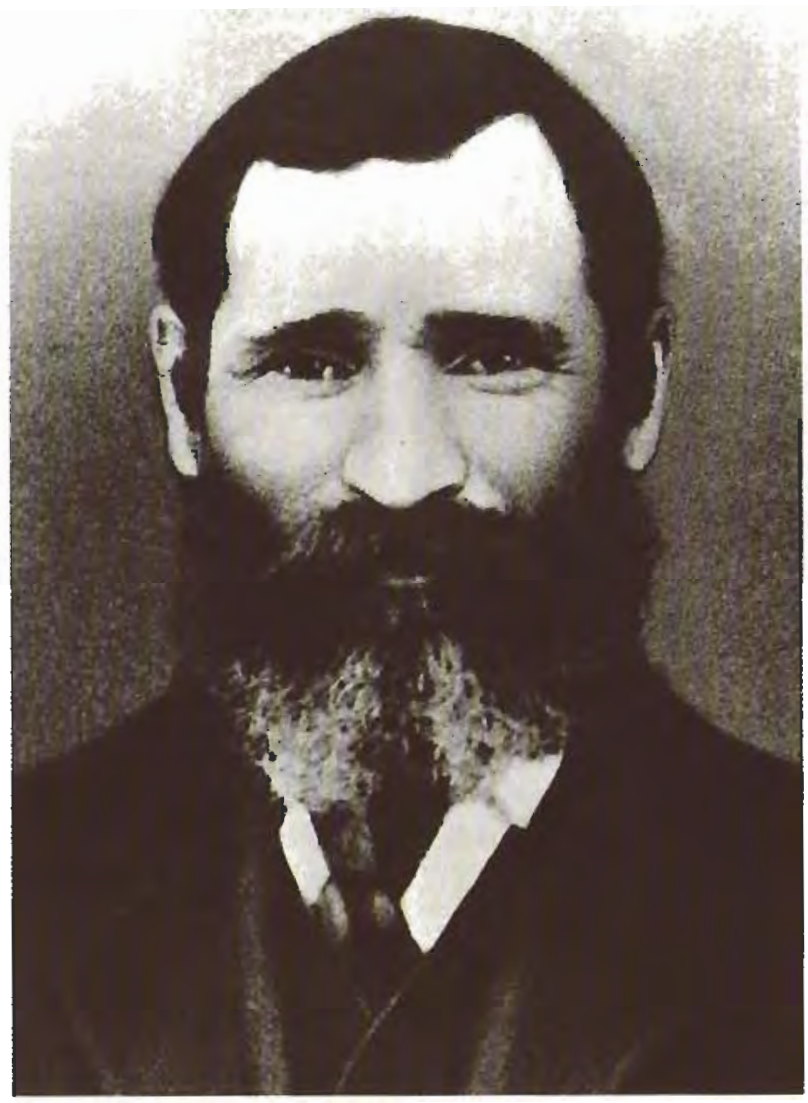


Vaal Rivers. At least 20 other diamonds turned up during the next two years, found by Griquas and Boers poking around in the gravels of the two rivers Isee Chalmers" "list of 20 diamonds" in Weakley, 1869; Atherstone, 1869).

Harry Emanuel, a well-known London jeweler who had written a textbook on gemstones (1865), sent mineralogist James Gregory to South Africa in 1868 to check out the discoveries. During his tour through the Cape Colony, Gregory did not see any rocks resembling the micaceous sandstones and mica schists that had been reported to be the source rocks for diamonds in Brazil (Claussen, 1841). Consequently, he declared that the discovery was "an imposture, a bubble scheme to drive up land values" (Gregory, 1868). He said that if there were any diamonds scattered about, they must have been brought there in the gizzards of ostriches. (Most birds swallow small stones to help their digestive system; he probably added the ostriches as an afterthought, hecause a few stones as large as several carats were found and offered for sale while he was in the area.)

Gregory's statements created an uproar in the Cape Colony (Atherstone, 1869). Before the debate really took off, though, an 83.5 (old) carat stone (later cut into a $47.69 \mathrm{ct}$ pear shape called the Star of South Africa; figure 6) was offered for sale by the same Van Niekerk who had been associated with the first (Eureka) diamond. This was on March 17, 1869, in Hopetown (L. Hond letter cited in Weakley, 1869). Van Niekerk got the stone from a Griqua shepherd named Swartbooi, who said that he had found it on the Sandfontein farm, which was also near the convergence of the Orange and Vaal Rivers. Van Niekerk gave Swartbooi all he possessed: 500 sheep, 10 head of cattle, and one horse (F. Steytler letter dated March 18, 1869, cited in Robertson, 1974, pp. 173-174). Van Niekerk then sold the stone to Lilienfeld Brothers, general merchants in Hopetown, for $£ 11,200$.

This event removed all doubts in the minds of most people in southern Africa, many of whom soon took to searching the sands and gravels of the Orange and Vaal Rivers. Because these early diggers knew little about alluvial mining, the earliest efforts were inefficient, recovering only diamonds of one carat and larger. Hübner (1871) wrote that in 1870 the earliest sieves were made of pieces of corrugated iron sheeting that had been pierced by nails to make holes, so the smallest sieve size was one fifth of an inch (5 mm). Consequently, only rough stones over one carat (about $5 \mathrm{~mm}$ in longest dimension) were retained. A year later, metal screens in wooden frames came into use, and screen sizes went down to one-sixteenth of an inch $(1.6 \mathrm{~mm}$, about $0.035 \mathrm{ct})$.

Most of the early diamonds were found in the Vaal River which, in the area near its confluence with the Orange River, flows over amygdaloidal basalt (in fact, andesite). The basalt forms good "trap sites" for diamonds, with rock bars, potholes, and gravel bars. A party of prospectors from Natal, led by a Captain Rolleston, was credited as the first to establish that diamonds not only occur lying on the surface, but also can be recovered by actually digging in the gravel. Their first successful dig was near the German mission station of Pniel on January 4, 1870 ("Captain Rolleston's party finds diamonds ..., ") July 16, 1870; Noble, 1874).*

In the early years, then, the South African diamond fields did not appear to differ much in character from diamond fields in India, Borneo, or Brazil. Diamonds were found in alluvial deposits, that is, unconsolidated sands and gravels located in stream beds, flats, and banks, as well as the terraces of rivers. They were recovered by washing and sieving gravels, using picks and shovels and locally made sieves that were often ingenuously combined to make primitive equipment such as rocking cradles. The energy was provided by manual labor; horses and mules were only used for transport.

The First Dry Diggings. In late 1869 and in 1870, however, diamonds were also found in places that were nowhere near an obvious watercourse. They were recovered from reddish loamy surface sand and from yellowish friable calcareous dry mud underlying the red sand. The yellowground was later found to overlie harder, compact, bluish gray rock-blueground-which eventually was called kimberlite. Because they were far removed from any obvious streams or rivers and lacked water during the summer season, people referred to them as "dry" diggings in contrast to the alluvial "river" or "wet" diggings.

Most lay accounts of the history of the South African diamond fields (see, e.g., Dickinson, 1965) state that the Koffiefontein and the Jagersfontein were the first kimberlite pipes discovered, but early correspondence reveals that diamonds were recov-

\footnotetext{
${ }^{*}$ In-house records of the Pniel Mission note the local find of a diamond in 1859. Dunn (1871) mentioned the existence of an 18th-century missionary's map that has the words "here be diamonds" covering part of the Orange and Vaal River areas. Maps of this kind are not rare. The author has seen replicas of "missionary maps" with the words "here be diamonds" in Dutch or Spanish for various parts of the world.
} 
ered first from the pipes at Dutoitspan and Bultfontein. In July 1870, the foreman of the Jagersfontein farm, a man called De Klerk, found a $50 \mathrm{ct}$ diamond in a small dry creek on that property (Steytler, 1870). I have not found any early records on Koffiefontein. However, Beet (1931) states that the first diamond was found there by a transport rider (the equivalent of today's long-distance truck driver) named Bam, also in July 1870. Both finds were made in small tributaries of the Riet (Reed) River and were first considered river diggings. Yet, in a paper delivered before the Geological Association in London in December 1872 (Paterson, 1873), the statement is made that the Jagersfontein and Koffiefontein workings do not represent alluvial diggings, but rather they are similar to the Dutoitspan diggings, which by that time were already regarded as being other than river diggings.

In fact, in a letter dated November 4, 1869, Fred Steytler wrote that during a visit to Dutoitspan farm the preceding month, he saw hundreds of gamets and some diamonds in limy soil (Robertson, 1974, p. 219). Not only is this several months before the first report of diamends at Jagersfontein and Koffiefontein, but Steytler's association of red garnets and diamonds suggests that early prospectors had an inkling that the occurrence of gamets was in some way related to the occurrence of diamonds.

Draper (1905) stated that the first diamonds not associated with a watercourse were actually found on Bultfontein farm sometime before November 1869. He claimed that he was present in a small store on the Vaal River on November 6, 1869, when Comelius Duplooy walked in and showed him a few diamonds that he had found in the mud with which he built his house at Bultfontein. The mud came from the edge of a large pan (i.e., a large shallow depression) named Du Toit's Pan about $25 \mathrm{~km}$ (16 miles) east of the Vaal River diggings. Further excavations revealed more diamonds in the small quarry and also at a spot $500 \mathrm{~m}$ further north along the edge of the pan, on the neighboring farm owned by Adriaan van Wyk (called Dorstfontein, but once part of the original Dutoitspan farm). These two mud quarries became the two famous diamond pipe mines, Bultfontein and Dutoitspan (figure 7).

Another account states that the diggings on Bultfontein started in September 1869 (report by F. S. Philipson-Stow, cited in Robertson, 1974, p. 221). However, J. B. Robinson, a well-known early digger and diamond buyer, claimed that on his first trip to the Vaal River at the end of 1868 , he purchased some

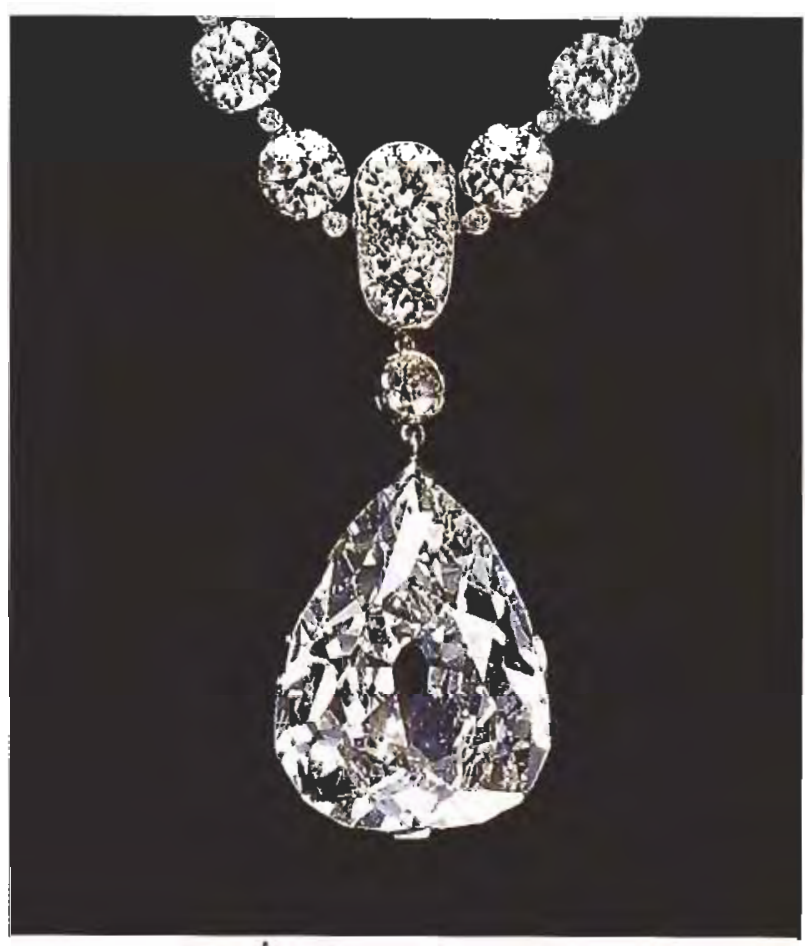

Figure 6. The 1869 discovery of the large diamond from which this $47.69 \mathrm{ct}$ pear shape known as the Star of South Africa was cut sent many people to the Orange and Vaal Rivers to start digging for diamonds. Photo courtesy of the Central Selling Organisation.

pebbles (which he had recognized as diamonds) from Mrs. Van Wyk at Dutoitspan (Murray, 1873).

Discovery of the De Beers and Kimberley (the Big Hole) Pipes. These first two dry diggings (Bultfontein and Dutoitspan; Jagersfontein and Koffiefontein were still considered wet diggings in 1870) did not generate much interest, both because the diamonds were small (Higson, 1870) and because living and digging conditions were not very pleasant on the hot, dry plains. Most would-be miners left for the Vaal River in January 1870. Summer was at its height, the water had run out (Babe, 1872), and they had heard of the Rolleston party's success in finding diamonds at Pniel. In May 187I, Richard Jackson and party left the river diggings to check out a rumor and found a lone Boer named Comeilsa (probably Comelissen, a common surname in Dutch/digging for diamonds in a depression on a farm adjoining Bultfontein and Dorstfontein (Dutoitspan) to the west. This farminsightfully named Vooruitzigt ("Foresight," or "Expectation")-belonged to two brothers, Johannes 
Nikolaas and Diederik Amoldus De Beer. Because the diamonds at this dry digging were plentiful and relatively large, the place was soon overrun by miners in what came to be known as the De Beers Rush (Williams, 1905).

Two months later, in mid-July 1871, diamonds were found at the foot of a low hill formed of porous calcareous rock, Gilfillan's Kop, which was $3.5 \mathrm{~km}(2$ miles) west of the De Beers Rush. This marked the start of the De Beers New Rush and became the Big Hole (later the Kimberley mine). The credit for this discovery is usually given to the Rawstorne party, originally from Colesberg, who were digging at the original (later "Old") De Beers Rush. One night when the party's cook Damon was drunk and boisterous, the other men sought to get rid of him by telling him to go and dig "on that hill over there." He did, and found a diamond. The hill was proclaimed a public digging on July 21, 1871. It was subsequently renamed Colesberg Kopje (Williams, 1905).

However, Sarah Ortlepp, wife of an Orange Free State surveyor, claimed to have found the first stone by accident while picnicking in the shade of a tree on
Gilfillan's Kop a week or two before Damon was told to dig there (this story is first told in Beet, 1931). Gilfillan's Kop was probably the only place for miles around De Beers Rush to have trees and shade for a picnic, as depicted in a Mary Barber watercolor that is now in the Kimberley mine museum. This diamond stayed in the Ortlepp family until recently, when it was placed on permanent loan at the Africana Museum in Johannesburg (J. Hummel, pers. comm., 1995).

A large tent settlement grew up between Old De Beers and De Beers New Rush. On July 5, 1873, this settlement became the town of Kimberley. These two dry diggings, together with Bultfontein and Dutoitspan, fit within a circle $3.5 \mathrm{~km}$ across. They developed into the four famous diamond mines located on kimberlite pipes in and around the town of Kimberley: the Kimberley (the Big Hole), De Beers, Bultfontein, and Dutoitspan mines (again, see figure 4). From the earliest days, they produced some spectacular stones (figures 8 and 9).

The dry diggings quickly became far more important than the river diggings. Not only did they contain more diamonds per volume of ground being dug

Figure 7. Dutoitspan, one of the earliest "dry" diggings, was also one of the first to be developed into a pipe mine. Here, in this late-19th-century woodcut, hundreds of miners' tents lie among shallow prospecting pits on the original Dutoitspan farm. The Dutoitspan mine can be seen in the distance. From Williams, 1905.

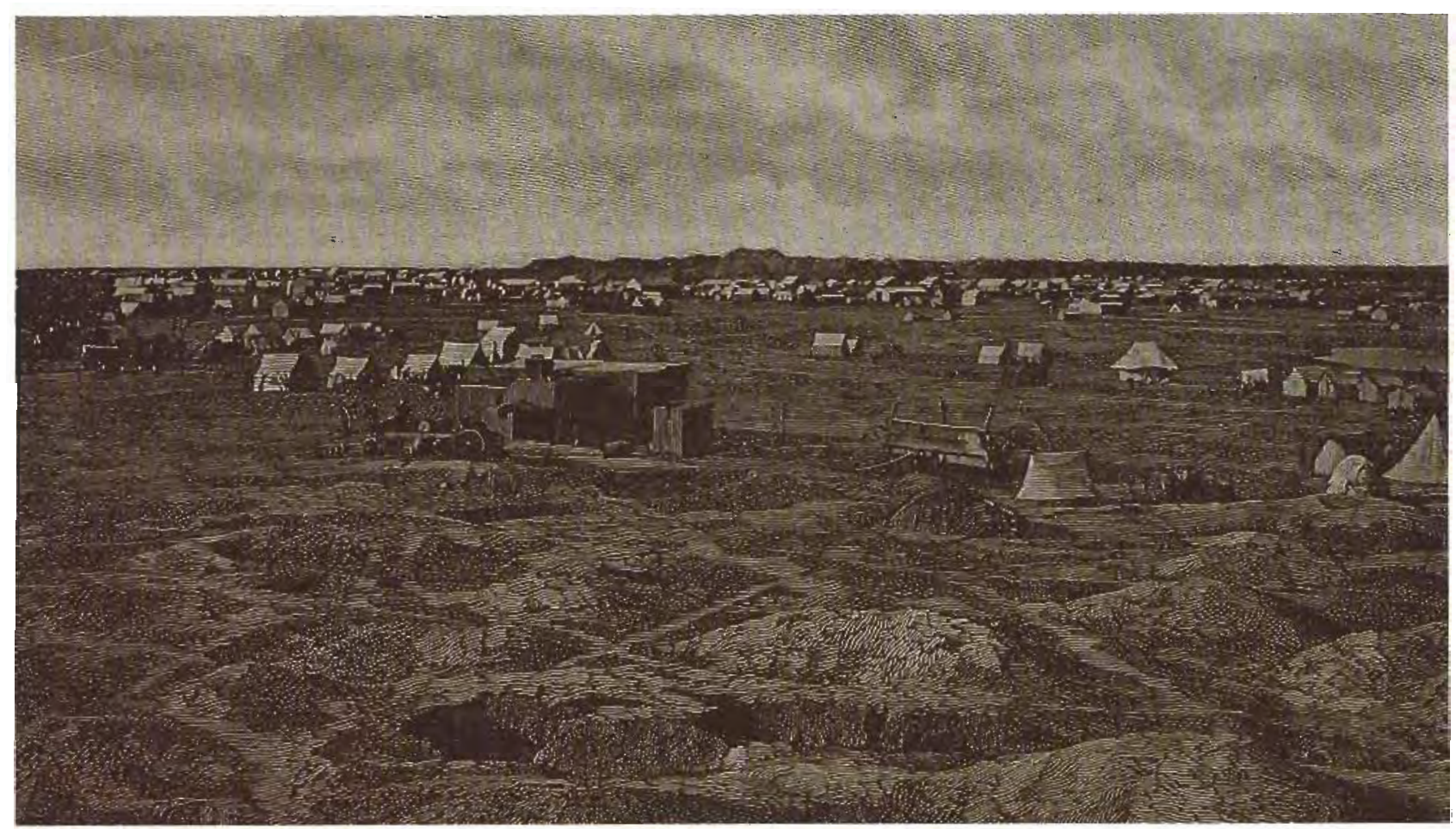




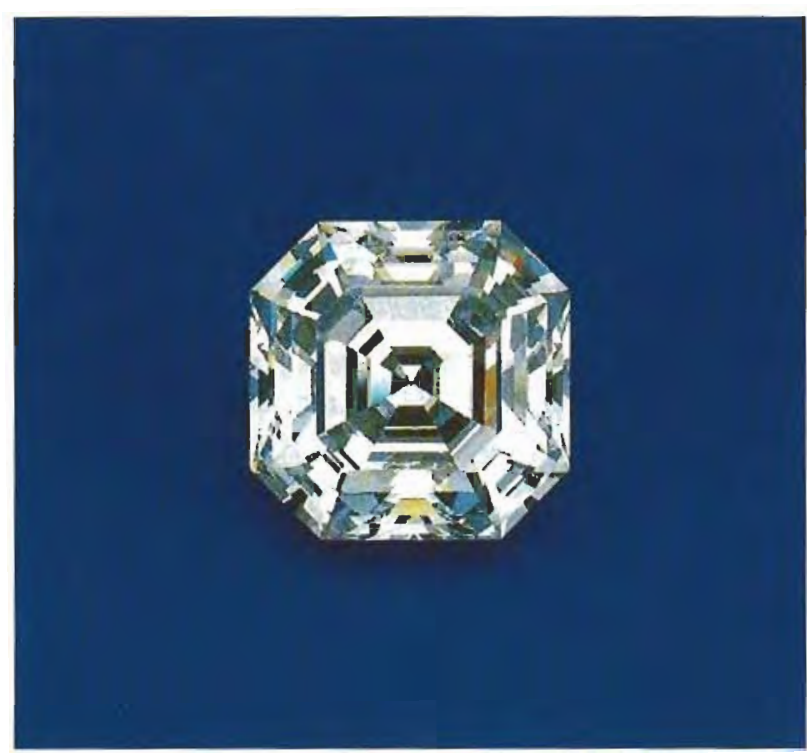

Figure 8. The $55 \mathrm{ct}$ Porter Rhodes diamond (named for the man on whose Kimberley mine claim it was found) was cut from a 154 ct stone considered to be the finest African diamond found up to 1880 (Krashes, 1993). Photo courtesy of Harry Winston Inc.

up, but the fine-grained dry yellowground was much easier to process than the gravels. (Hard "blueground" had not yet been encountered.)

Although as many as 20 other kimberlite pipes were found around Kimberley over the next 20 years, not until September 1890 was another economically successful kimberlite found-no more than $8 \mathrm{~km} / 5$ miles) from the Kimberley town center (Williams, 1905). First called the Premier, the name was changed to Wesselton when a larger pipe found in Transvaal in 1903 was also called the Premier.

Consolidation of Claims. In the early days of the dry diggings, individual miners were allowed to register one claim of $31 \times 31$ feet square. After 1872 , when the pits on some claims became deeper than those on adjoining claims, and passageways between them started to fall in (figure 10), two claims were allowed to combine; in 1874, blocks of 10 claims were permitted. Eventually, the friable yellowground ran out and gave way to hard, compact blueground, which was more difficult to work. Gradually, syndicates and small companies bought out the individual miners (Reunert, 1893).

Around 1874, the open pits in the Kimberley mine had reached such depths (about $30-40 \mathrm{~m}$ ) that mechanization was essential to haul the ore to the surface (see, e.g., figure 11), with mules used to provide the power. Water caused further problems; to pump it out, steam engines made their first appearance in 1875 (Williams, 1905). By 1878, fallen reef (the non-diamond-bearing rock that forms a wall around the pipe) became a very serious problem and cost much money to remove. To raise the necessary capital for mechanization of the mining operation and removal of the fallen reef, the smaller claims were consolidated into major new companies. By 1883, all of the diggings at the Kimberley mine were controlled by a few companies. The most important of these were the Kimberley Central Diamond Mining Company (controlled by Barnato Brothers) and the "French Company" (actually the Compagnie Française des Mines de Diamant du Cap de Bonne Espèrance), which was run by the Rothschild family in Paris. By the end of 1882, the excavations were 120 $\mathrm{m}$ (400 feet) deep and underground mining had start-

Figure 9. One of the most famous stones found at Dutoitspan is this $253.70 \mathrm{ct}$ well-formed crystal known as the Oppenleimer diamond, which was recovered in 1964. Courtesy of the Smithsonian Institution.

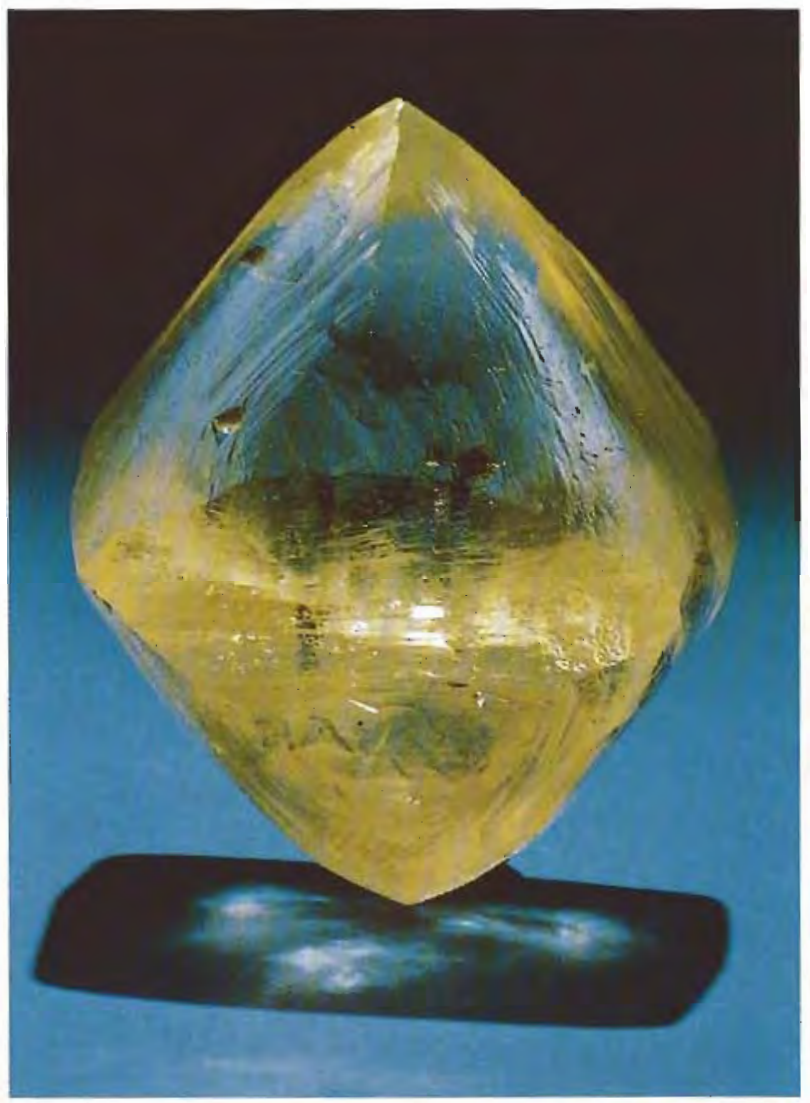


ed; by 1884, almost all ore at Kimberley came from underground workings (Reunert, 1893).

The De Beers mine was $100 \mathrm{~m}$ deep in 1882 and was experiencing the same problems as at Kimberley. In 1880, Cecil Rhodes and his partners formed the De Beers Mining Company and began to consolidate all claims on this pipe into a single entity. De Beers Mining's first technical manager was American mining engineer Gardner F. Williams, who had been manager of an alluvial gold mine near Oroville, California, that had also produced a few hundred small diamonds (Kunz, 1885)! Williams (1886) wrote the first detailed paper on the technical aspects of operating the De Beers mine, which by 1884 had started underground workings. By 1887, all claim blocks in the De Beers pipe had been bought up by De Beers Mining. In the Kimberley pipe, Rhodes's De Beers company first purchased the "French Company" and then, in 1888, bought out Barnato Brothers' "Kimberley Central" to form De Beers Consolidated Mines (Williams, 1905). By 1889, De Beers had completed leasing arrangements for the Dutoitspan and Bultfontein pipes.

Kimberley-the World's Center for Economic Diamond Pipes. As the 19th century drew to a close, many other kimberlite pipes were discovered in South Africa, but they either were not diamondiferous or were low in grade or small in volume. Furthermore, it appeared that the closer the pipes were to Kimberley, the bigger and better they were. Therefore, Kimberley

Figure 10. By 1872, as this early photo shows, the walls between pits at the Kimberley mine had started to collapse, so new mining laws allowed two claims to combine. By 1874, blocks of 10 claims were permitted. Photo from Williams, 1905.

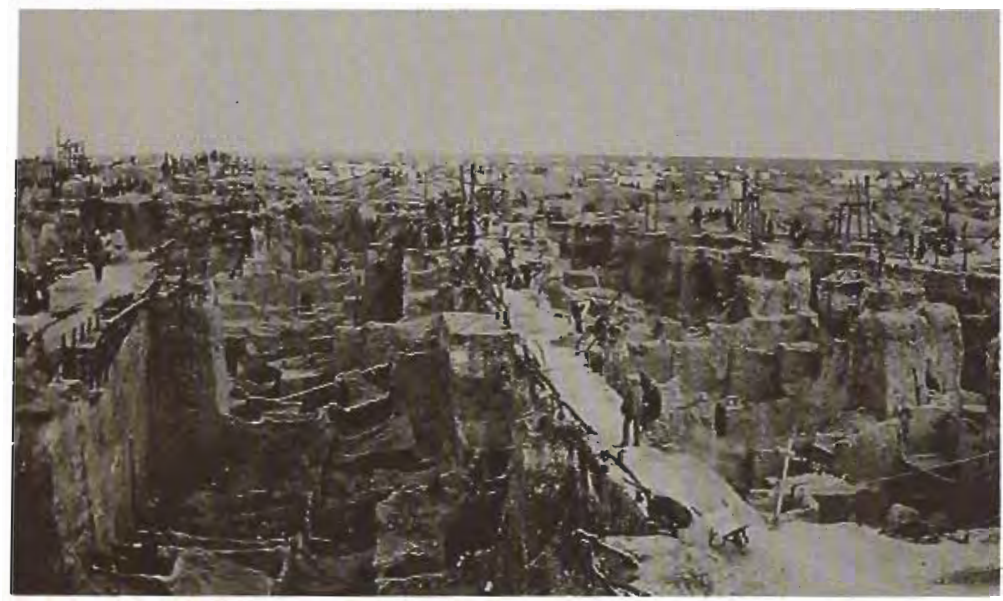

was considered the world center for economic kimberlite pipe mines (C. Rhodes, quoted in De Beers Annual Report, 1896). The discovery of the first Premier (later called Wesselton) pipe in September 1890, less than $8 \mathrm{~km}$ from Kimberley, seemed to confirm this view. Eventually, all five economic pipes around Kimberley, plus the Jagersfontein and Koffiefontein pipes in the Orange Free State, were either owned, leased, or gradually purchased by De Beers Consolidated Mines, which controlled the output of all economic diamond pipes in South Africa by the turn of the century. (The purchase of all shares in Koffiefontein was completed in 1911.)

Discovery of the Premier Pipe. The Kimberley area's dominance of diamond production in South Africa changed in 1903 when the large Premier pipe was discovered $30 \mathrm{~km}$ east of Pretoria, the capital of the Transvaal $-500 \mathrm{~km}$ northeast of Kimberley. Alluvial diamonds and a few small pipes had been found in the general area as early as April 1897 (Molengraaff, 1897), but the Boer War (1899-1902) halted prospecting activities. By 1898, Thomas Cullinan, a builder and local brick manufacturer from Pretoria, had recognized that alluvial diamonds found on the Bijenestpoort (Beehive Pass) farm came from the adjoining farm to the east, Elandsfontein. A diamond was actually found right beneath the wires of Elandsfontein's western fence (Helme, 1974). Elandsfontein's owner, Prinsloo, would not sell and threatened to shoot any diamond prospectors trespassing on his farm. Nevertheless, in November 1902, after Prinsloo's death and the end of the Boer War, Cullinan was able to purchase the farm from Prinsloo's widow and heirs for $\$ 52,000$ (Helme, 1974).

In January 1903, Cullinan's prospecting pits revealed diamondiferous kimberlite ("Premier . . .," 1903), early evidence of a very large, 32 ha (79 acre) diamondiferous kimberlite pipe |"The Premier mine. ..," 1903; Merensky, 1904). Although a De Beers geologist sent to inspect the discovery in January 1903 reported (to their relief) that it was a "flash in the pan" (Helme, 1974, pp. 54-56), his assessment proved very wrong when the largest stone ever found - the Cullinan diamond, at over 3,024 (old) carats 3,106 metric carats $)-$ was recovered there January 25, 1905 (Molengraaff, 1905). Other large stones have since been found at the Premier mine, which proved to be a strong competitor in overall production to the De Beers mines (see "History of Diamond Production" in Part II). Thomas Cullinan went on to serve as Chairman of the Premier (Trans 
Mines from 1904 to 1931. At the height of mining, in 1927, the gravels produced 2 million carats of diamonds. Although activity has dropped off dramatically, the field is still worked sporadically.

Namaqualand Coast. Diamonds were discovered in coastal deposits, actually dune valleys, near Lüderitz in South West Africa (now Namibia) in April 1908 (figure 17; see below). In August 1925, amateur prospector Jack Carstens found the first diamond on the coast south of the Orange River, in South Africa, near Port Nolloth (Reuning, 1928; Carstens, 1962). The area was soon overrun by amateur prospectors as well as some professional geologists, such as Hans Merensky and Ernst Reuning.

Merensky was famous for discovering the platinum-bearing horizon that bears his name ("Merensky Reef") in Transvaal Province (Lehman, 1955), and Reuning had much experience with the coastal diamond deposits in South West Africa. In January 1927, Merensky discovered the "oyster line" in the Alexander Bay region. He found that the diamonds in this area are associated with a raised beach terrace (a terrace formed when sea level was higher than at present), which also contained many oyster shells (Wagner and Merensky, 1928). He pegged his now-famous oyster line and formed the H. M. Syndicate.

The sudden increase in diamond production due to the Lichtenburg discoveries, combined with the richness of the Namaqualand coastal deposits, caused the South African government to pass the Precious Stones Bill in November 1927-forbidding further prospecting and digging for diamonds on state-owned land in Cape Province (Kunz, 1929). However, the H. M. Syndicate was awarded its discovery claims (a prospector who finds a new pipe or alluvial deposit is awarded two claims), and mining started in 1928. The remainder of the oyster line was taken over by the South African government and proclaimed the Alexander Bay State Alluvial Diggings ("Government intends ...," 1928). In 1930, the State Alluvial Diggings acquired all the discovery claims in the area, including those of the H. M. Syndicate. They were partly privatized in 1989 into the new Alexander Bay Development Corp. ("Alexcor"), which has since been granted three sea concessions.

Other important diamond deposits were discovered in 1926 at the mouth of the Buffels River at Kleinzee. They were also exempt from the prohibitions of the Precious Stones Bill, because the area was a freehold property. Johannesburg jewelers G. S.
Ronaldson and J. van Praagh, who had bought the property, invited the Consolidated African Selection Trust (CAST), a diamond mining company in the Gold Coast (now Ghana) to evaluate the deposit. CAST's prospectors, George and Ronald Dermody, two brothers originally from Ireland, submitted a favorable report (Selection Trust in-house reports). To develop these deposits, the Cape Coast Exploration Company was incorporated in January 1928. CAST originally obtained nearly a third of the shares, but Anglo American and Barnato Brothers had bought out everyone by January 1939 (Greenhalgh, 1985). Systematic mining started in 1929, was suspended in 1932, and resumed in 1937. The Kleinzee deposit was mined out in 1958, but adjoining deposits to the north at Tweepad and Dreyerspan and to the south at Annex Kleinzee are still being worked.

The Precious Stones Bill was rescinded in 1960. By then, De Beers had purchased almost all the farms (and their mineral rights) along the Namaqualand coast from near Port Nolloth south to the mouth of the Olifants River, a distance of $320 \mathrm{~km}$ (200 miles). These areas were mapped and prospected in 1958 and 1959 / the author participated in these surveys as his first job), and in the early 1960s several minable reserves were outlined along the coast at Koingnaas and Hondeklip Bay. Mining started at Koingnaas in 1978 ("Koingnaas alluvial diamond mine . . ., 1978) and is still ongoing. De Beers and Transhex are

Figure 13. Once depths of $120-150 \mathrm{~m}$ were reached, mining companies at pipes like the Wesselton (shown here) had to go underground.

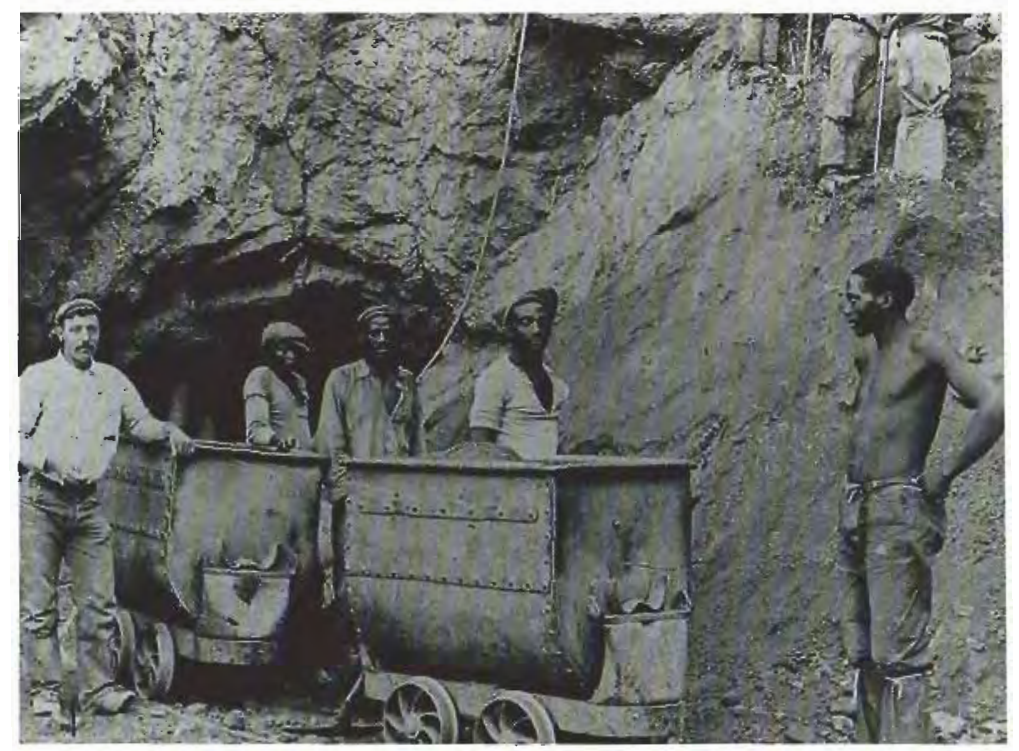


presently mining at Hondeklip Bay. Minable reserves were also located at Langhoogte in ancient river terraces along the Buffels River, the largest of the dry river beds that are common along the Namaqualand coast. Mining started there in 1978 and is still ongoing.

In 1966, Baxter Brown and Hugh Jenner-Clarke were the first to discover alluvial diamond deposits in fossilized channels (earlier courses, bends, or meanders that are now covered by terrace sands and gravels of the present river bed) in the lower course of the Orange River's south bank (Wilson, 1972). These deposits became the Ochta mine and Baken Diamante, which produced large, good-quality stones. Other fossilized channels have since been found on the north bank.

Off-Shore Deposits. Texas oil man Sam Collins formed the Southern Diamond Corporation in 1961 to prospect for and eventually mine diamonds from the sea floor off the coast of Namagualand. De Beers took over management of Southern Diamond in 1964. Although prospecting and research have continued, there has as yet been no systematic mining operation.

The South African government has divided the sea concessions into 14 blocks, further subdivided into zones A (tidal), B (shallow), and C (deep sea), as illustrated in Gurney et al. (1991). Several junior mining companies (notably Benguela Concessions) recov-

Figure 14. The Premier mine, here shown in an early-20th-century photo, was mined open pit until it closed in 1936. Reopened in 1946 as an underground mining operation, it is still being actively worked. Photo courtesy of De Beers.

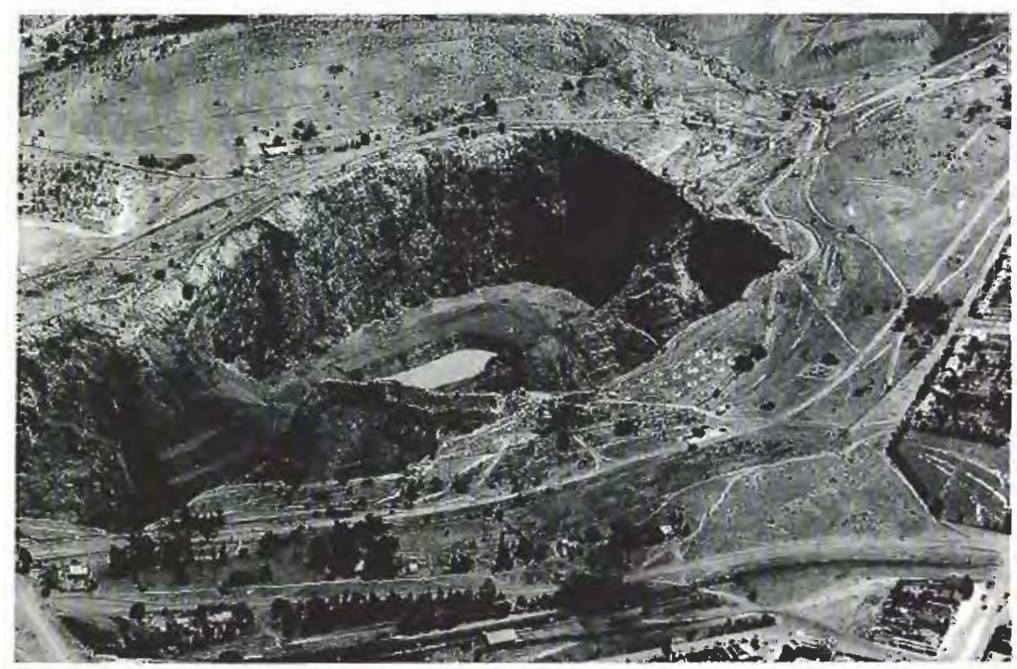

er diamonds from submerged beaches in tidal zone A, operating from the shore. Divers supported by long air hoses guide powerful suction devices that transport gravel and sand to the beach where they are washed and sorted. In zone B (shallow sea), small boats are also used, but such operations frequently have to be suspended because of rough seas (Gurney et al., 1991).

Discovery of the Finsch pipe. In 1963, De Beers purchased a large pipe prospect from Alastair Fincham and Wilhelm Schwabel, who named their find Finsch after the first three letters of their surnames. Because of the 1927 Precious Stones Bill, the prospect was first pegged as an asbestos claim in 1958. When this law was repealed in 1960, the prospectors started to work their claim for diamonds and offered it to De Beers. The latter declined the offer on the advice of one of their geologists, who had gotten unecononic results from a bulk sample collected in one large deep pit. The prospectors then dug a long, shallow trench right across the pipe and found patches of high-grade kimberlite (author's own files). De Beers later agreed to pay 4.5 million Rand (about US $\$ 4$ million) to purchase this 17.9 ha (44 acre) pipe ("Finsch Diamonds (PTY) Ltd. acquired by De Beers," 1963). Finsch came into production in 1966 and was officially opened February 27, 1967. It soon produced 3 million carats per year. Finsch became an underground mine in September 1990, when a depth of $430 \mathrm{~m}$ was reached (figure 18).

Discovery of the Venetia Pipe. Although one would think that South Africa had been thoroughly prospected over the years, a whole new field of diamondiferous kimberlites was recently discovered in the northern Transvaal. In the mid-1970s, while prospecting for copper on the Venetia farm, Saturn Mining (a subsidiary of the Anglo Vaal group) and African Selection Trust intersected a small kimberlite fissure in one drill hole (Selection Trust in-house reports). De Beers acquired a lease from Saturn Mining to prospect for kimberlites, and in 1979/1980 De Beers geologists found 12 pipes. The Venetia mine, on the largest of the pipes (12.7 ha [3I acre]), started production in 1991 and was officially opened August 14, 1992. It reached its planned production of 5 million carats per year in 1993, and is scheduled to produce this amount annually for the next 20 years.

Future Prospects. The discovery of the Venetia pipe, which came more than 100 years after the original kimberlite discoveries around Kimberley, showed 
that new, important, economic pipes can still be found in South Africa. Diamondiferous fissures may still await discovery in the central part of the Orange Free State, the eastern and western Transvaal, and the northern Cape areas. It is also possible that a large pipe, covered by soil or calcrete, could be found in an area that is difficult to prospect. Thus, although the country has been prospected for a long time, there is still hope for new economic discoveries.

\section{LESOTHO}

\section{(Formerly Basutoland)}

The first concession to prospect for diamonds in Basutoland (now Lesotho) was granted by the Basuto paramount chieftainess to Colonel Jack Scott in 1954 ("Colonel Jack Scott . . .," 1978). Several kimberlite occurrences were described in the first official report on the geology of Basutoland (Stockley, 1947), but it was specifically stated that none had yet been found to contain diamonds.

In 1959, De Beers geologists joined Jack Scott's prospectors and two post-graduate students, Barry Dawson and Peter Nixon, from the newly formed Research Institute for African Geology at the University of Leeds, England, where the first modern research on kimberlites was started (Dawson, 1962; Nixon et al., 1963). De Beers withdrew in 1962, and the Kao and Letseng-la-Terai pipes (found in 1954 and 1957, respectively) were declared public diggings. A large, pale brown 601.26-ct stone was found in the Letseng pipe in May 1967, and in 1968 RTZ took over prospecting and evaluation of the Kao and Letseng pipes. Notwithstanding the occasional finds of large diamonds, RTZ concluded that the pipes were not economic and withdrew in 1972.

De Beers, however, negotiated an agreement in 1976 to reinvestigate the 15.9 ha Letseng pipe, located at $3,000 \mathrm{~m}$ altitude in the Drakensberg Mountains. When mining started in 1977 on a 3.7 hal (9 acre) section, Letseng became the highest diamond mine in the world ("Lengthy wait . . ," 1978). The mine closed in October 1982.

\section{SWAZILAND}

Although a diamond find was reported in 1895 from Mahash in the Lebombo Range ("Diamonds found near Mahash . ..," 1895), it was not confirmed. After De Beers geologists found the alluvial Hlane diamond deposit in 1973, they traced the origin of the diamonds to the small, 2.8 ha (6.9 acre) Dokolwayo pipe in 1975 (Hawthorne et al., 1979). De Beers ultimately decided that both the diamonds and the pipe were

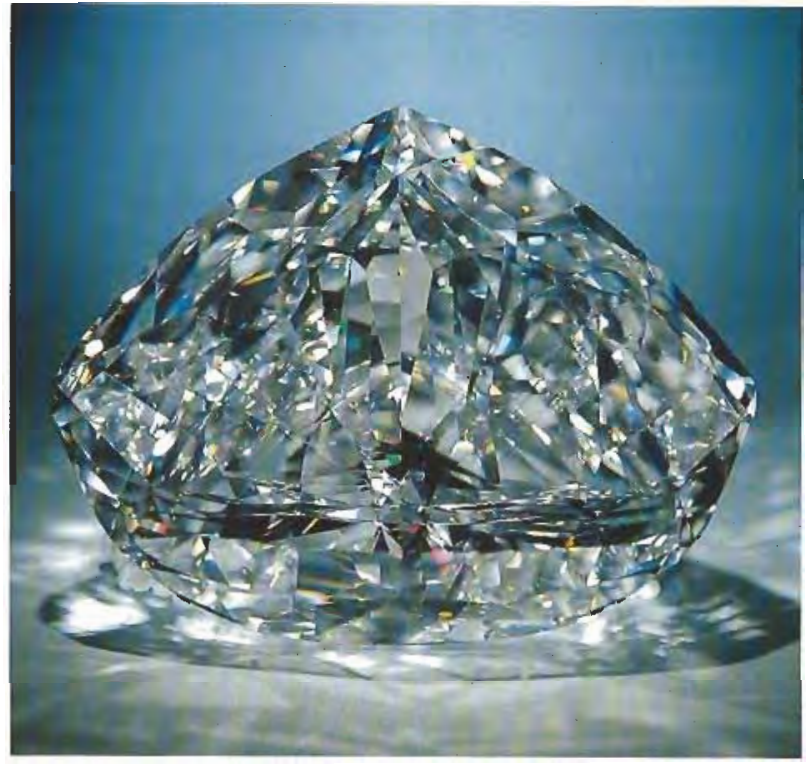

Figure 15. Many superb diamonds have recently come from the Premier mine, including the $599 \mathrm{ct}$. diamond from which this $273.85 \mathrm{ct} D$-color (internally flawless) Centenary diamond was cut. Photo courtesy of De Beers.

too small to sustain a substantial mining operation. However, in 1983 Transhex started a mine that is still active, producing about 50,000 carats per year.

\section{NAMIBIA}

\section{(Formerly South West Africa)}

Namibia has been a steady producer of small but good-quality diamonds since the early 20th century. In fact, today it ranks first in the world in value per carat. Virtually all of the diamonds found are recovered from raised beach terraces and, in recent years, from near-shore and even ocean-floor deposits.

First Discoveries in 1908. The first alluvial diamonds were found in April 1908 by railway worker Zacharias Lewala, near Kolmanskop (Merensky, 1909; Levinson, 1983). Diamonds occurred in loose sand in valleys between the dunes along the coast from Lüderitz to Bogenfels, $100 \mathrm{~km}$ to the south (again, see figure 17). The mining settlements of Kolmanskop and Elizabeth Bay were founded in 1909.

Some areas were so rich that the workers had only to crawl along the sand to pick up diamonds (Kaiser, 1926). Security must have been a nightmare. The deposits yielded large quantities of small diamonds of very good quality, and by 1912 South West Africa had captured $12 \%$ of world production by vol- 
ume (Wagner, 1914). Surface mining continued until World War I intervened. In 1915, the country was occupied by South Africa and ownership of the mines was transferred to the Custodian of Enemy Property.

Birth of CDM in 1919. After the war, Consolidated Diamond Mines of South West Africa ICDM, created specifically for this purpose by Emest Oppenheimer) took over, reorganized, and purchased the properties of the various German companies. (In 1917, Oppenheimer had formed the Anglo American Corporation of South Africa [AAC] to raise venture capital for investment in the Witwatersrand gold mines; AAC took a large shareholder position in CDM in 1920.) Mining of the Kolmanskop and Elizabeth Bay areas resumed through the 1920s and 1930s, but in 1928 diamondiferous marine terraces (raised beaches) were found in the areas north of the mouth of the Orange River ("Another great diamond discovery," 1928; Kunz, 1929). The terrace diamonds were much larger (average about $1.5 \mathrm{ct}$ ) than the small diamonds found at Elizabeth Bay and Kolmanskop (average from 6 to 7 stones per carat), and they were of equal or better quality. Thus, most mining operations had shifted to the latter area by 1935, and by 1939 the settlements at Kolmanskop and Elizabeth Bay had been abandoned.

Figure 16. Some small dikes, like this "fissure" at Bellsbank (known as the Bobbejaan), have also been mined successfully.

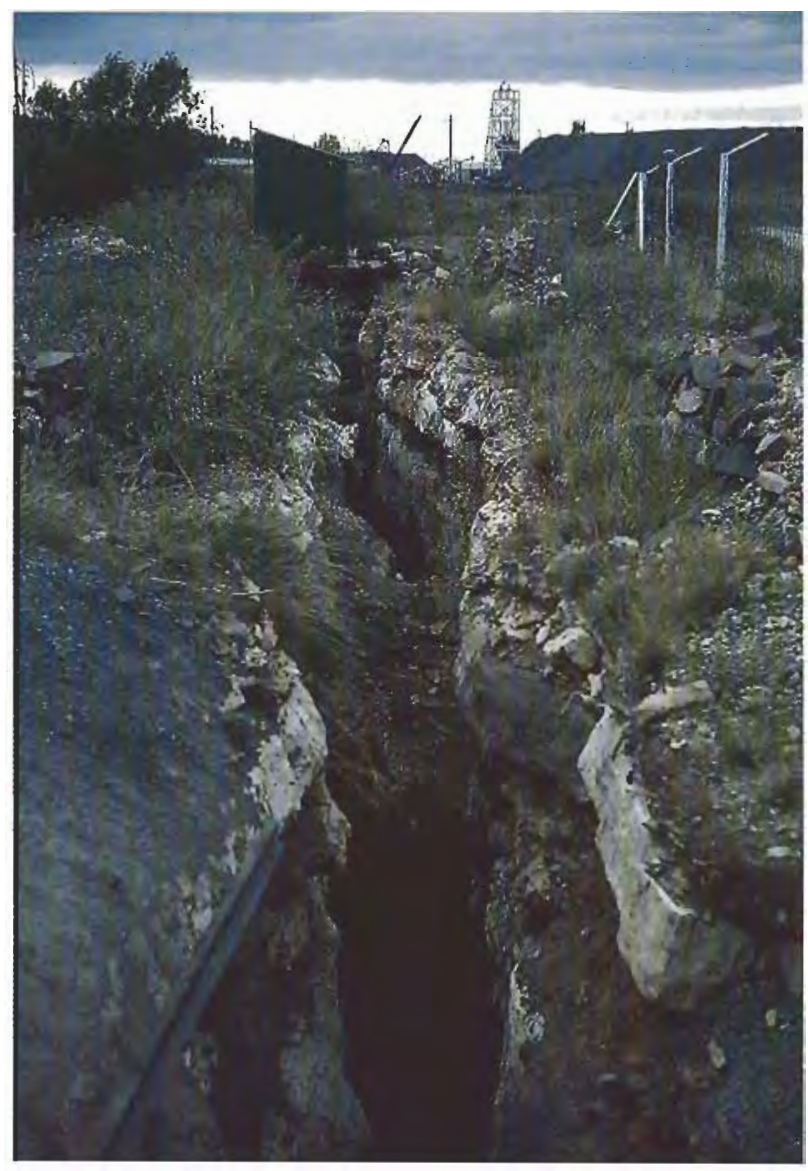

Oranjemund. CDM headquarters moved from Lüderitz to the new township of Oranjemund (Orange mouth $=$ mouth of the Orange River) in 1943. In this area, diamonds are found in sands and gravels of ancient marine terraces. These occur up to $35 \mathrm{~m}$ above present sea level and are covered by an overburden of dune and beach sand as much as 12-15 m thick (Hallam, 1964; Murray et al., 1970). Huge earth-moving machinery is used to remove the overburden.

Offshore and Foreshore Mining. In the early 1960s, the idea emerged that diamonds would also be found in submerged marine terraces farther out to sea. In 1961, Sam Collins formed Marine Diamond Corporation ("Diamonds mined off the seabed," 1962) and obtained a sea-mining concession. Marine Diamond worked the sea floor near the coast from October 1961 to July 1963, producing 51,000 carats. However, unpredictable weather, rough seas, inadequate technology and prospecting, and excessive capital expenditures prevented financial success.

In 1963, CDM purchased 29\% of Marine Diamond and agreed to incorporate CDM's diamondmining rights to the tidal zone into a new sea-mining joint venture. After initiating a large-scale prospecting and underwater-mining research program, in 1967 CDM leased the marine diamond mining rights from Collins's company. In the meantime, in 1965, CDM had begun foreshore mining in the shallower parts of the tidal areas by building groynes (rigid structures built out from the shore) using old metal bedsteads and canvas sheeting to keep back the sea (Borchers et al., 1970). Although operations were suspended in April 1971, they resumed in 1973 with new, improved methods (still in use today) by which huge sand walls are pushed up to $200 \mathrm{~m}$ from the shore, and once-submerged terraces are mined down to about $20 \mathrm{~m}$ below sea level (figure 19).

Submarine Mining. After several years of research and prospecting, actual sea-bed mining operations started in 1991 in Namibian waters as deep as $100 \mathrm{~m}$. Although first-year production was modest-about 125,000 carats-by 1994 diamond production from submarine deposits already accounted for $31 \%$ of Namibia's total production (De Beers Annual Reports for 1991 to 1994).

These deposits are believed to extend to the edge of the continental shelf (up to $100 \mathrm{~km}$ from the shore) in water over $100 \mathrm{~m}$ deep, so mining costs will be high. However, the quality of the diamonds recov- 
ered is exceptionally good and the deposits are huge (Gurney et al., 1991; Meyer, 1991).

New Mines. CDM has also opened two new mines on land in recent years: Elizabeth Bay, on the coast, $30 \mathrm{~km}$ south of Lüderitz; and Auchas, on the north bank of the Orange River, $45 \mathrm{~km}$ inland. Elizabeth Bay's ore reserves have been calculated at 38 million tonnes at 6.6 carats per 100 tonnes, that is, more than 2.5 million carats of good-quality small stones (Boting and Russel, 1993). The mine, started in June 1991 , is projected to produce 250,000 carats annually for 10 years.

Reserves at the Auchas mine are 12.3 million tonnes of ore (under 45 million tonnes of sandy overburden), with 3.6 carats of diamond per 100 tonnes (Croll and Cooper, 1993). Plans are for the mine, started in July 1990, to produce 45,000 carats of goodquality, larger-than-average diamonds annually for 10 years.

CDM Becomes Namdeb. After intense negotiations, CDM was restructured in November 1994 as a new company, Namdeb Diamond Corporation (Namdeb), owned in equal shares by De Beers Centenary and the Namibian government (see, e.g., "Namibia: The govemment is . ..," 1995, and "Namibia: De Beers ...," 1995).

Kimberlites. The first kimberlite in Namibia was discovered at Gibeon Village in 1889. By 1906, several other occurrences had been identified as far as $50 \mathrm{~km}$ east of Gibeon, near Mukorob, and $85 \mathrm{~km}$ south of Gibeon, near Brukkaros (Scheibe, 1906). The site "near Brukkaros" where a 2.75 (old) ct dianond was allegedly found in 1893 could not be confirmed, and the kimberlites in the Gibeon field proved to be barren (Janse, 1975). Namibia has at least four other kimberlite fields, but all proved to be barren.

\section{BOTSWANA}

\section{(Formerly Bechuanaland)}

Botswana is the second largest diamond producer by volume on the African continent, and the largest producer by total value in the world. Diamonds are recovered from two of the largest-known kimberlite pipes-Orapa and Jwaneng-and one small one, Letlhakane (figure 20). There is no production from alluvial sources. These kimberlite pipes were discovered only relatively recently, because a large part of the country is covered by a thick layer of desert sand.

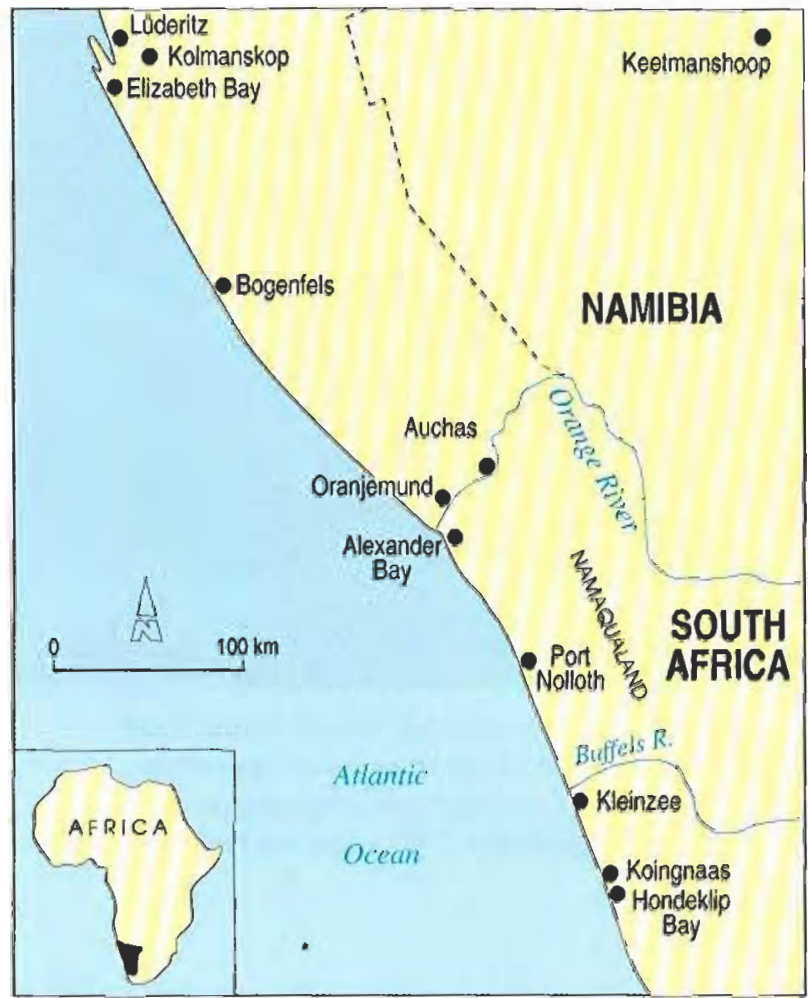

Figure 17. This map shows the key areas where diamonds are being mined in on-shore and off-shore deposits along the coasts of Namaqualand (in South Africa) and Namibia. The broken line above the Orange River in Namibia represents the outer boundary of the restricted diamond area. The inset shows the outline of Namibia.

Early Discoveries. Although earlier finds of alluvial diamonds had been rumored (Wayland, 1949), the first officially recorded discovery-of three small diamonds $\{0.27,0.14$, and $0.02 \mathrm{ct})-$-was made in the Motloutse River near Foley in 1959, by a prospecting party led by Humphrey Willis of CAST/Selection Trust (Boocock, 1960, 1965). The diamonds could not be traced to a host kimberlite; rather, they were believed to come from an intermediate host, a conglomerate of the Ecca series (Selection Trust in-house report), and the company allowed their lease to lapse.

Discovery of Orapa. Most of central Botswana is covered by the Kalahari Desert, a vast expanse of red sand dunes that lie in long rows separated by valleys covered in grass, bushes, and clumps of thom trees, but no surface water. The De Beers subsidiary Kimberlite Searches started prospecting in 1955 in 


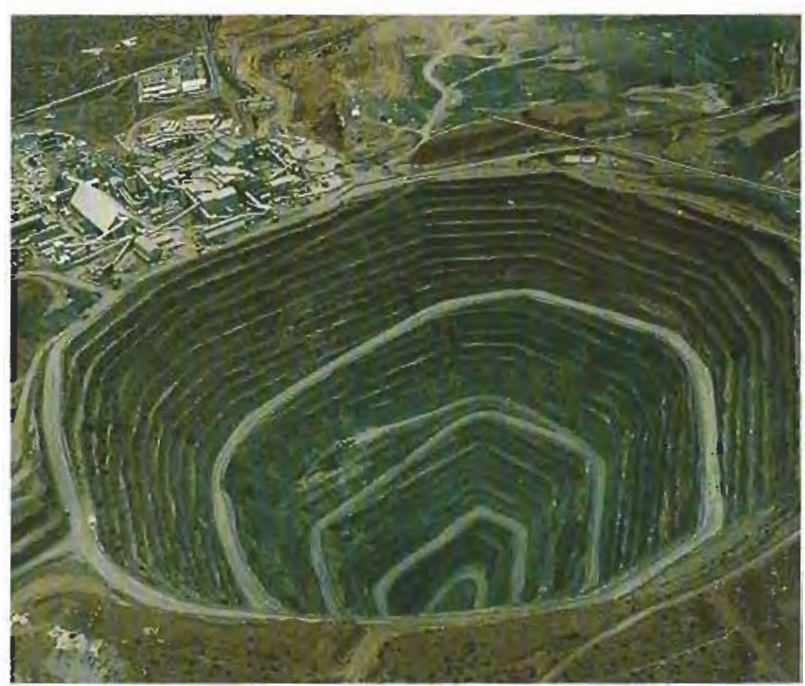

Figure 18. The Finsch mine has been a major South African diamond producer since it was opened in 1967. Mining went underground when the pitshown here in September 1990-had reached a depth of $430 \mathrm{~m}$.

the eastem (less sandy) parts of the country, and in 1965 they found two nondiamondiferous pipes near Mochudi (Boocock, 1965). After 1960, they had also moved into the Motloutse River area, farther west than CAST had prospected. In April 1967, 12 years after they had started, they found a large diamondiferous kimberlite pipe near a cattle post called Orapa (figure 21). The De Beers prospecting teams (then called De Beers Prospecting Botswana) were directed by Dr. Gavin Lamont, with Jim Gibson the regional team leader. The actual discovery of the Orapa pipe, however, was made by Manfred Marx, a junior geologist l"Young prospector ...," 1969; "How the Orapa pipe was discovered," 1971). Marx said to me once that "everyone has one great piece of luck during their lifetime of prospecting, and I had mine in my very first job" (pers. comm., 1994).

Orapa turned out to be a pipe topped by an ovalshaped crater $1,560 \mathrm{~m} \times 950 \mathrm{~m}$ and about $80 \mathrm{~m}$ deep. At 106.6 ha (263 acre), it was the world's second largest economic kimberlite lafter the 146 ha of Tanzania's Mwadui pipe).

Bechuanaland became the independent state of Botswana in 1966, and in 1969 De Beers Botswana Mining Company (Debswana) was registered in Gaborone to develop Orapa, originally as an $85 / 15$ joint venture of De Beers and the Botswana government. The Orapa mine started production in July 1971 and opened officially on May 26, 1972, with a planned production of 2.5 million carats per year ("Orapa opening . . .," 1972; Allen, 1981). In 1975, the joint venture was reorganized on a 50/50 basis, and the principals decided to double the size of the Orapa operation. Orapa reached a peak production of 6 million carats in 1991, and produced 5.4 million carats in 1994 (De Beers Centenary Annual Reports for 1991-1994).

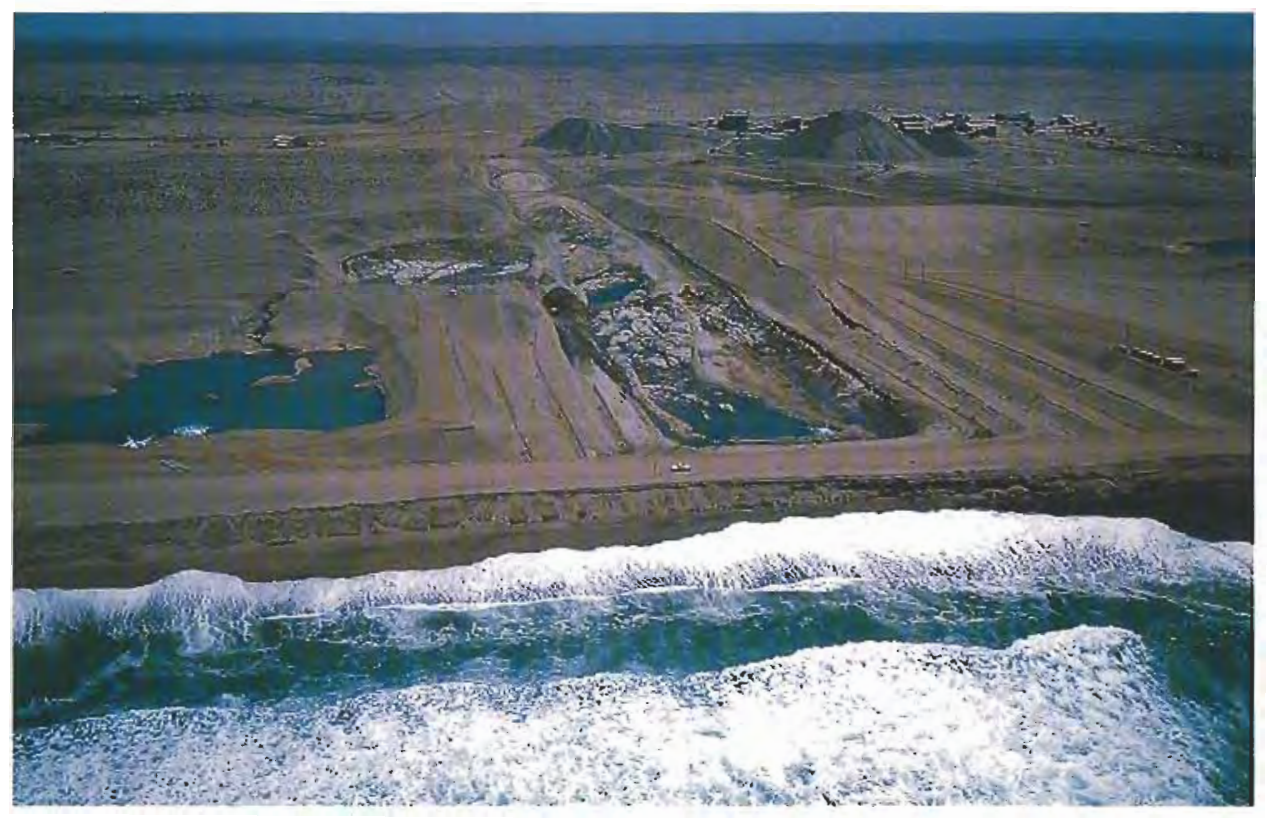

Figure 19. By building huge walls of sand to keep back the sea, CDM has mined vast tracts in Namibia that were once the sea floor. Photo courtesy of De Beers. 
Discovery of Letlhakane. The Orapa pipe is part of a field that contains 30 known kimberlites. One year after Orapa was discovered, De Beers Prospecting found two small pipes, Letlhakane 1 and 2 (11.6 and 3.6 ha, respectively), about $48 \mathrm{~km}$ southeast of Orapa. These two pipes came into production in 1976 at a projected annual rate of 300,000 carats (Allen, 1981); in 1994, they produced 1.1 million carats (De Beers Centenary Anmual Report for 1994).

Discovery of Jwaneng. After the successful discoveries of Orapa and Letlhakane, De Beers ventured south into the Kalahari Desert and in 1973 discovered the Jwaneng pipe. Eleven pipes were eventually found 25-60 $\mathrm{m}$ under a cover of Kalahari sand. Jwaneng forms three lobes-south, central, and northeast-with a combined area of 54 ha (133 acre) under $50 \mathrm{~m}$ of sand. Mining started in the central, 27 ha lobe (figure 22) in February 1982, at a planned annual production rate of 5 million carats (Chadwick, 1983); in 1994, Jwaneng produced 9 million carats.

Prospecting by Falconbridge and Others. In 1974, a Falconbridge/Superior Oil joint venture began prospecting in Botswana combining indicator-mineral sampling with aeromagnetic surveys (which will be described in detail in Part III). Over the next five years, they found approximately 60 kimberlites under $20-60 \mathrm{~m}$ of sand. Although one of these pipes, the Gope 25, appeared to have potential, none of these kimberlites has yet proved economic.

In 1982, Superior Oil withdrew and Falconbridge formed two joint ventures with De Beers: Gope Exploration, to develop Gope 25; and Debridge Exploration, to investigate other areas (Jones, 1982). No economic discoveries have been announced to date.

Since 1988, smaller companies based in Australia, Canada, and South Africa have joined the search for diamonds. As of 1994, at least 140 kimberlites in 11 clusters or fields were known. Except for Orapa, which outcrops (again, see figure 20), all other kimberlites in Botswana lie under 20-100 m of sand. No new major discoveries have been announced thus far, but it is highly probable that at least one more significant diamond pipe mine will be found.

\section{ZIMBABWE}

\section{(Formerly Southern Rhodesia)}

Historically, Zimbabwe has been a small producer of diamonds from alluvial and minor kimberlite

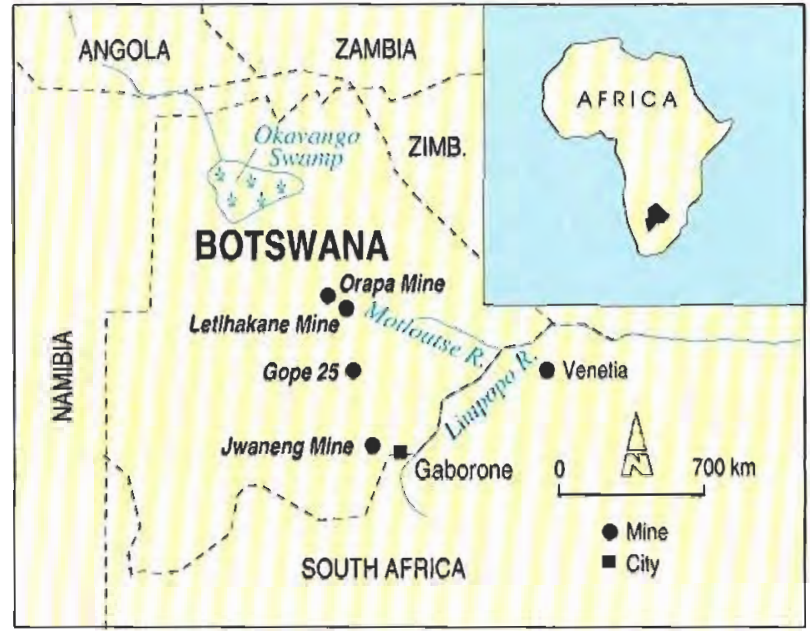

Figure 20. The key mines in Botswana are the Orapa, Jwaneng, and Let lhakane. The first of these, the Orapa pipe, was discovered only in 1967. The Gope 25 pipe is still being evaluated.

deposits. Today, the River Ranch mine, a single pipe, appears to be economic. Because the geologic framework of Zimbabwe favors kimberlite intrusions, it has been the object of considerable prospecting activity in recent years.

Alluvial Deposits. H. R. Moir, who had dug diamonds at Vaal River, was the first to discover alluvial diamonds in the Somabula Forest area, in 1903 (Mennell, 1906; Macgregor, 1921). By arrangements made in 1892 with the British South Africa Company (founded by Rhodes), De Beers had an exclusive license to mine all minerals, including diamonds, in Rhodesia. Therefore, Moir contacted prominent entrepreneur Sir James Willoughby, who formed the South African Options Syndicate and used his influence to obtain a diamond-mining concession from De Beers. Mining operations started in 1905 but seldom amounted to more than a few hundred carats annually; they finally ceased in 1938.

Kimberlite Pipes. The first kimberlite pipe, Colossus, was found in 1907, about $80 \mathrm{~km}$ southwest of Gwelo (Mennell, 1908), but it was less than colossal—only 900 by $150 \mathrm{~m}$. Several smaller pipes were later found nearby, but all proved to be uneconomic.

De Beers geologists found more kimberlites in the central part of the country in the late 1930s, but the results were not encouraging. Kimberlite Searches has prospected intermittently since the 
in the Lualaba River during 1906 to 1909 (Ball, 1912) were traced to two groups of diamondiferous, but uneconomic, kimberlites along the eastern and western rims of the Kundelungu Plateau. Although some of the pipes were large (such as Talala, at 50 ha), grades were low, less than $0.1 \mathrm{ct}$ per tonne, and the diamonds were very small, averaging 15 stones per carat (Bardet, 1974).

Instead, the major diamond deposits in the Belgian Congo were found in two areas $350 \mathrm{~km}$ apart: Tshikapa in Western Kasai, and Mbuji-Mayi in Eastern Kasai Province (figure 23).

Tshikapa. Belgian prospector Narcisse Janot found the first diamond- $0.1 \mathrm{ct}$-in the Tshikapa area on November 4, 1907, in the Kasai River at Mai Munene (Ball, 1912). He was a member of a field party led by American geologist M. K. Shaler, which was prospecting for the newly formed Société Internationale Forestière et Minière du Congo (Forminière), a joint venture between (first King Leopold and then) the Société Genérale de Belgique and the American Guggenheim-Thomas Ryan group.

The Tshikapa area was inhabited by the fiercely independent Batshioko tribes, which resented the intrusion of foreigners, so a detachment of soldiers accompanied the prospecting party. One can visualize the conditions when Janot was panning for gold: It was raining hard, the natives were hostile, and he had been away from home for nearly half a year. When he found some color in his pan (a few specks of yellow gold), he quickly put the concentrate, which included a bright shiny crystal, in a bag that eventually ended up in Brussels with all the other samples. P. Lancsweert, who inspected Janot's samples, recognized the crystal as diamond, and Shaler's accurate field notes helped them locate the probable discovery site (Buttgenbach, 1910; "How diamonds were discovered . . ., 1925). The find was confirmed by Janot in 1911, when ruffled tribal feelings had settled down. Mining started in 1913, and the Tshikapa deposits became a steady producer of good-quality small stones (Bardet, 1974). They are still active.

At Tshikapa, diamonds are found in unconsolidated sands and gravels in and along the Kasai River and its tributaries-Tshikapa, Longatshimo, Tsiumbe, and Lubembe-which flow north from the Lunda region of Angola into the Kasai region of Zaire (Ball and Shaler, 1914). Early mining was carried out in small, scattered, and isolated workings with one or two Belgian supervisors and about 50 local workers.

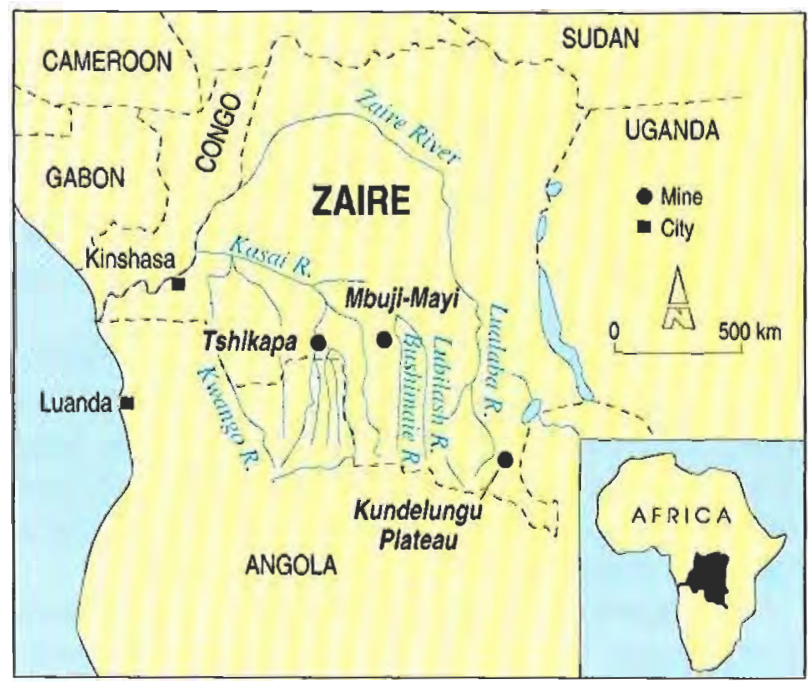

Figure 23. Although some uneconomic pipes have been found along the eastern and western rims of the Kundelungu Plateau, the major diamond deposits in Zaire are in the region of the towns of Tshilkapa and Mbuit-Mayi.

European-organized mining ended abruptly in 1961, after independence was attained, and has never been resumed. Virtually all mining is now done by locals, who produce several hundred thousand carats a year from this area.

After 1967, the national government tried to control the diamond industry in Westem Kasai by allowing expatriate companies to set up buying offices. Nevertheless, even today production and trade still are not controlled by the central government. The number of carats purchased at the official buying offices rose from a few thousand in 1968 to close to 600,000 annually in the late 1980s and 1990s.

Mbuji-Mayi. The first diamonds at Bushimaie (now called Mbuii-Mayi) were found in December 1918 by George Young, a young Scottish geologist working for the Compagnie des Chemins de Fer du Bas-Congo au Katanga (Bécéka), a railway company that had been granted huge tracts of land for mineral exploration (Polinard, 1929). Young found more than 8,800 small diamonds in one location in a tributary of the Bushimaie River. The Société Minière du Bécéka was formed in 1919, and mining started at once with Forminière managing the operation for Bécéka.

Diamonds were found in gravelly soil and rock debris on low watersheds along the Bushimaie River and its tributaries, Kanshi, Mudiba, and Katsha. They 
came from several small kimberlites, discovered in 1946 (de Magnée, 1947). Their pipe stems are very narrow and are topped by small craters that contain a complex mixture of sandstone, kimberlite, clay, calcite, opal, and chalcedony rock and mineral fragments. Diamonds were found in eluvial (directly overlying the kimberlite) and colluvial (transported down slope), as well as alluvial deposits in the stream beds.

The diamonds were generally of poor quality $195 \%$ bort), but the grade was high ( 5 carats per tonne) and mining was low cost (Bardet, 1974). Consequently, large quantities were produced, reaching a peak of 18 million carats in 1961. This enormous production has made a significant impact on the world diamond market.

Bécéka was reorganized after independence into a new Belgian company, Sibeka (Société d'Investissements de Bécéka, later Société d'Entreprises et d'Investissements), which formed a subsidiary Miba (Société Minière de Bakwanga) to manage the MbujiMayi mines. The Congolese (after 1970, the Zairian) government took a $50 \%$ equity in Miba; this was increased to $100 \%$ in 1971 , and settled back to $80 \%$ in 1973. Miba produced only 4.6 million carats in 1992, whereas private licensed contractors and artisanal labor produced about 10 million from the same area, and illicit production for all of Zaire is estimated at another 10 million. After 75 years of large-scale surface mining, however, the easily accessible eluvial and colluvial deposits are becoming depleted, and operations are gradually moving to the alluvial deposits, which are being mined by large dredges. Yet the international financing needed to refurbish the Miba plant and dredges has not been forthcoming because of Zaire's unstable political climate.

From 1961 to 1967, almost all production left Zaire illegally through various African countries, notably the Central African Republic and Congo (Congo-Brazzaville). Diamond exports from Congo reached 6 million carats in 1967, but almost all of the stones exported actually came from the Tshikapa and Mbuji-Mayi areas, because there are no diamond mines in Congo. Accordingly, Congo is not listed as a producer of diamonds in figure 2; diamonds exported from this country are assigned to Zaire's production.

\section{ANGOLA}

An important African diamond producer, Angola exports up to 2 million carats of good-quality diamonds annually, primarily from alluvial deposits. Like Zaire, though, an unstable political situation has hindered both organized mining operations and prospecting. If unrest subsides, and order is restored,
Angola will undoubtedly be an even greater player on the international market.

Alluvial Fields. The discovery of diamonds in the Tshikapa area of what is now Zaire encouraged the Guggenheim-Ryan group to extend prospecting farther upstream into the Lunda area of Angola. In July 1912, Donald Steel found the first diamonds in tributaries of the Luembe River (Legrand, 1984). The Companhia de Pesquisa Mineiras em Angola (Pema) was founded in Lisbon in 1913 to mine the diamonds (Castro, 1929). Production, which started in 1916, rose gradually from 100,000 carats in 1921 to nearly 800,000 carats in 1940.

In 1917, Pema was reorganized into the new Companhia de Diamantes de Angola (Diamang), and four years later Diamang acquired prospecting rights to virtually all of Angola (except the coastal strip) until 1971. Barnato Brothers and Anglo American purchased large share holdings in Diamang in 1923, and secured a contract that all diamonds produced would be sold to the Diamond Syndicate ("The Angolan diamond deal," 1923). To date, nearly all Angolan diamonds come from alluvial deposits in the Andrada and Lucapa areas of northeastern Lunda Norte and the Cuango River (figure 24). Diamond production reached a peak of 2.4 million carats in 1973.

In 1971, Diamang was restricted to about 50,000 $\mathrm{km}^{2}$ in northeastern Lunda Province, and the Consorcio Mineiro de Diamantes (Condiama) was formed to take over the rights to all other areas. This consortiurn included the Angolan provincial government, De Beers, and Diamang. The newly independent Angolan government took over Diamang in 1976, and the following year made it a subsidiary of Empresa Nacional de Diamantes de Angola (Endiama); Diamang was finally dissolved in 1986. The complex history of the Angolan diamond industry up to the middle of 1992 is summarized in "The Angolan diamond experience" (1992), with an update to early 1995 provided in Gordon (1995). This includes the roles played by Endiarna, Mining and Technical Services (MATS, an affiliate of De Beers that operated from 1979 to 1985), Sociedade Portuguesa de Empreendimentos (SPE), Rhodesian Selection Trust (RST), De Beers, and the Unita forces /whose invasion of the Cuango diamond fields in February 1985 led to the withdrawal of most foreign technicians).

With the onset of civil war following independence in 1975, official production dropped to a low of 270,000 carats in 1986. Although official annual production rose to about one million carats recently, 
Angola has a large illicit production (estimated at an additional one million carats in 1992) that is largely caused by the recurrent demobilization of soldiers. Once released, the soldiers would rather dig for diamonds than retum to their farms. Illicit production decreases when military operations take place or heavy rains impede digging.

A law passed in October 1994 gave Endiama the exclusive right to all diamond deposits in Angola and empowered it to enter into joint ventures with foreign companies (with government approval). Licensed artisanal digging (manual diamond mining by local residents) is allowed in places where largescale mining would not be lucrative.

Present alluvial operations are carried out in the Lucapa area by ITL Mining (a subsidiary of RST) on behalf of the Sociedade Mineira de Lucapa, a joint venture of Endiama and SPE. Alluvial operations in the Cuango Valley, which stopped when Unita forces reinvaded the diamond workings in November 1992 , are starting up again. It is estimated that about $80 \%$ of Angolan diamonds produced in 1980-1992 came from this area (Gordon, 1995).

Kimberlites. There is only very limited production from eluvial and colluvial gravels overlying pipes such as the one at Camafuca-Camazomba, which was found in 1952 in the Chicapa River near Calonda (Real, 1958). This sinuous $3 \mathrm{~km}-$ long body, up to 550 m wide, covers an area of 75 ha (185 acres). Many other diamondiferous kimberlites were discovered in the Lunda Norte district and elsewhere in Angola in the 1970s (Jourdan, 1990, gives a total of 600). Prospecting activities by Diamang and Endiama indicated that at least five pipes in Lunda Norte may be economic: Camutue, Caixepa, Camatchia, Camagico, and Catoca. However, Angola's intemal strife has hindered evaluation and development of pipes throughout the country. The Russia-Sakha Diamond Corporation (Almazy Rossii-Sakha), in a joint venture with Endiama and Brazil-based Odebrecht, was reportedly planning to develop the 66 ha Catoca pipe for open-pit mining. Development was delayed, though, as government forces recaptured the Catoca area only in July 1994 (Gordon, 1995).

De Beers is currently negotiating rights to prospect off-shore for submarine deposits and at several areas on-shore (Gordon, 1995).

\section{CENTRAL AFRICAN REPUBLIC (C.A.R.)}

The Central African Republic has been a small but steady producer of diamonds since the mid-1930s.

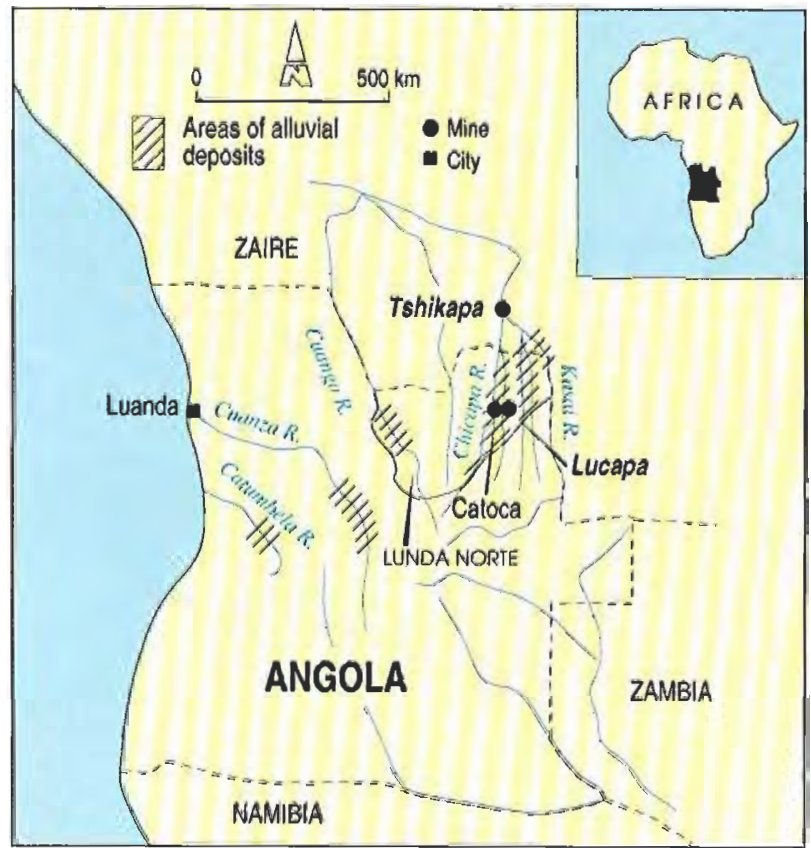

Figure 24. Most of the diamonds found to date in Angola come from alluvial deposits in the Lucapa and Cuango areas, in Lunda Norte Province.

All diamonds produced there to date came from alluvial deposits. The first diamonds were found in 1914 near Bria in the south central part of the country (Middleton, 1932). The major diamond-producing regions are Carnot-Berbérati in C.A.R.'s wet southwest and Mouka Ouadda in its dry northeast. Diamond production started in 1931. Mining was carried out by small French companies until independence was attained in 1961, after which syndicates of locals assumed control.

Since the early 1980s, foreign companies have again been allowed to participate in mining ventures. Osborne and Chappell Company attempted to dredge the Mamberé River (the main trunk river in the Camot-Berbérati region) during 1989-1990, but the project was terminated because the results could not support a large mechanized mining operation.

Prospecting programs to evaluate the allegedly extensive colluvial deposits in the BaminguiBangoran area of the northeastern Mouka Ouadda region have been proposed since 1984. Canada-based United Reef recently raised venture capital to evaluate this project (Roux, 1994), and they started smallscale mining in Jume 1995.

Official plus unofficial production in C.A.R. is estimated at 500,000 carats annually for the last 33 years (based on Mining Annual Review reports for 


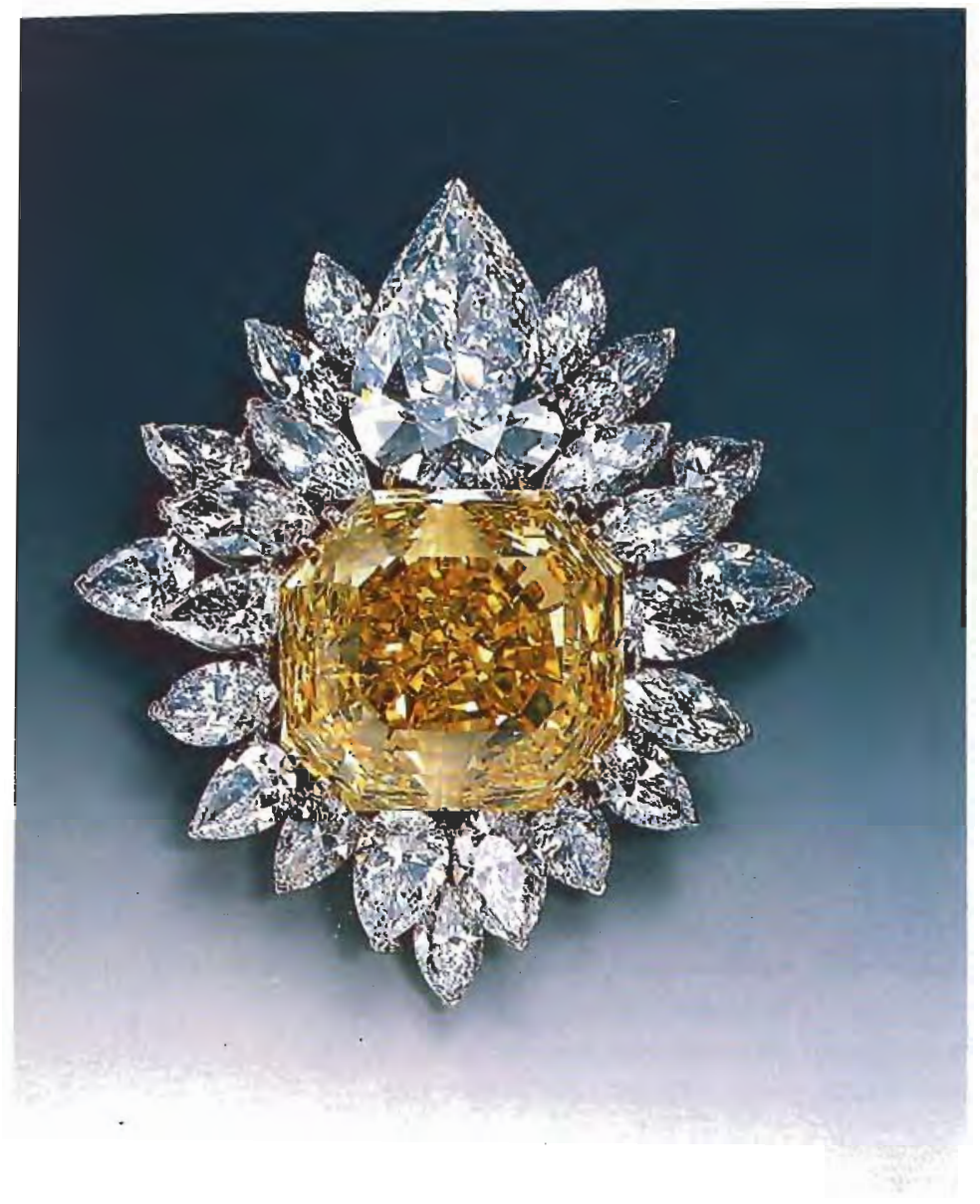

Figure 25. The $128 \mathrm{ct}$ fancy yellow Tiffany diamond was cut from one of the fabulous diamonds found in southern Africa, a 287 ct piece of rough reportedly recovered from a claim on the Kimberley mine in 1878. Photo by Josh Haskin; courtesy of Tiffany $\uplus_{1}$ Co.

1961-1994). Despite careful prospecting, no kimberlites or other primary host rocks have been found in this region, and all of C.A.R.'s diamonds are recovered from alluvial sources.

\section{CONCLUSION TO PART I}

The history of diamond and kimberlite discoveries in Africa spans nearly 130 years, from children playing with bright pebbles on De Kalk farm to high-technology exploration and excavation of tons of desert sand at Orapa and Jwaneng. During this period, all but two of the largest economic kimberlite pipes ever discovered were found (the other two are in Siberia). And several magnificent gem diamonds (see e.g., figure 25) were recovered. As a result, from 1872 to 1959 , Africa produced $98 \%$ of the world's diamonds by weight, and $96 \%$ by value. Although, as will be discussed in Part I, these percentages have dropped dramatically in recent years, Africa is still the single most important diamond producer among the seven continents.

Historically, most of the diamonds have been produced by alluvial diggings-along rivers and streams in South Africa, Angola, and Zaire, in particular-and by large kimberlite pipes, such as those clustered in the Kimberley area and the prolific pipes in Botswana. However, diamonds from coastal deposits, such as those off the Atlantic Coasts of Namibia and Namaqualand, promise to be the industry's greatest future resource.

Part II will continue the story, focusing on the diamond-producing nations of eastern and western Africa. This part will also look at Africa's role in the development of theories on the geology and origin of diamond, as well as methods of diamond prospecting and mining. Special attention will be paid to the history of diamond production in Africa and key developments from the 1870s to the present.

Acknowledgments: The author thanks Pat Sheahan of Konsult International Inc. in Toronto for assistance in collecting basic information and literature references; Roz Davies of Creative Cartography in Perth for making the maps and last-minute alterations; Drs. John I. Gurney and Alfred A. Levinson for constructive reviews, and Dr. Levinson especially for his meticulous scrutiny of the maps and references.

\section{REFERENCES}

Allen H.E.K. (1981) Development of Orapa and Letlhakane diamond mines, Botswana. Transactions of the Institution of Mining and Metallurgy (Section A: Mining Industry), Vol. 90, October; pp. A177-A191.

The Angolan diamond deal (1923) South African Mining and Engineering Joumnl, Vol. 34, Part 2, January 20 (p. 515) and Febriary 3 (p. 575).

The Angolan diamond experience: A case of wasted opportunity (1992) Diamond World Review, No. 71, pp. 44-59.

Another great diamond discovery (1928) South African Mining and
Engineering Journal, Vol. 40, Part 2 (November), pp. 573-574

Atherstone W.G. (1869) The discovery of diamonds at the Cape of Good Hope. Geological Magazine, Decade 1, Vol. 6, pp. $208-213$

Atkinson W.J., Smith C.B., Danchin R.V., Janse A.J.A. (1990) Diamond deposits of Australia. In F.E. Hughes, Ed. Geology of the Mineral Deposits of Australia and Papua, New Guinea, Vol. 1, Australasian Institute of Mining and Metallurgy, Melbourne, Australia, pp. 69-76.

Babe J.L. (1872) The South African Diamond Fields. D. Weslcy \& 
Co., New York (reprinted in 1976 by the Historical Society, Kinberley, South Africal, 105 pp.

Balfour 1. (1992) Fomous Diamonds, 2nd ed. Gemological Institute of America, Santa Monica, CA, 245 pp.

Ball S.H. (1912) Diamonds in the Belgian Congo, Engineering and Mining Journal, Vol. 93, No. 5 (February 31, pp. 268-269.

Ball S.H., Shaler M.K. (1914) Economic geology of the Belgian Congo, Central Africa. Economic Geology, Vol. 9, No. 7, pp. $605-663$.

Bardet M.G. (1974) Géologie du Diamant, Vol. 2, Gisements de Diamant d'Afrique. Bureau de Recherches Géologiques et Minières (BRGM), Memoire 83, Paris, France, 229 pp.

Bauer M.H. (1896) Edelsteinkunde (Gemology). C.H. Tauchnitz, Leipzig, $711 \mathrm{pp}$.

Beet G. (1931) The Grand Old Days of the Diamond Fields: Memories of Past Times with the Diggers of Diamondia. Maskew Miller Ltd., Cape Town, South Africa, 192 pp.

Beet G., Terpend T.L. \{1917\} The romance and reality of the Vaal diamond diggings. Diamond Fields Advertiser, Kimberley, South Africa, $117 \mathrm{pp}$.

Boocock C. (1960) Three small diamonds found in Bamangwato Tribal Territory. In the Annual Report of the Bechuanaland Geological Survey Department for the Year 1960, Vol, 4.

Boocock C. (1965) Mineral resources of the Bechuanaland Protectorate. Overseas Geology and Mineral Resources, Vol. 9, No. 4, pp. 369-417.

Borchers D., Stocken C.G., Dall A.E. (1970) Beach mining at Consolidated Diamond Mines of South West Africa Ltd: Exploitation of the area between the high-and low-water marks. In M.J. Jones, Ed, Mining and Petroleum Technology, Vol. 1, Proceedings of the Ninth Commonwealth Mining and Metallurgical Congress 1969, Institution of Mining and Metallurgy, London, pp. 571-590.

Boting G., Russel M. (1993) Elizabeth Bay mine: Reappraisal and commission of mining operations. In Abstracts of the Conference on Mining Investment in Namibia, Ministry of Mines and Energy, Windhoek, Namibia, pp. 83-88.

Bruton E. (1978) Diamonds, 2nd ed. Chilton Book Co., Radnor, PA.

Buttgenbach H. (1910) Description des Minéraux du Congo Belge. Annales du Musée du Congo Belge, Géologie, Paléontologie et Minéralogie, Série I-Géneralités-Fascicule l, pp. 5-10.

Buttgenbach (1925) Minéralogie du Congo Belge. Mémoires de la Société Royale des Sciences de Liege. Série 3, Vol. 13, pp. 108-117.

Captain Rolleston's party finds diamonds at Pniel (1870) Cape Argus, July 16.

Carstens J. (1962) A Fortune Through My Fingers. Howard Timmins, Cape Town, South Africa, $185 \mathrm{pp}$.

Castro L. de (1929) Companhia de Diamantes de Angola. Companhia de Diamantes de Angola, Lisbon, $50 \mathrm{pp}$.

Chadwick J.R. (1983) Jwaneng and Botswana: At height of diamond production. World Mining, January, pp. 64-68.

Claussen P. (1841) Note sur le gisement du diamant dans le grès rouge ancien. Bulletin de l'Académie Royale de Bruxelles, Vol. 8 , No. 5 , pp. 8-14

Coe F.E. \{1904\} The diamond placers of the Vaal River, South Africa. Transactions of the Institution of Mining and Metallurgy, Vol. 13, pp. 518-532.

Colonel Jack Scott finds first diamonds in Maluti Mountains, 1954 (1978) Indiaqua, No. 18, pp. 19-20.

Croll A.M., Cooper G. (1993) Auchas mine: Its discovery, its mining and its future. In Abstracts of the Conference on Mining Investment in Namibia, Ministry of Mines and Energy, Windhoek, Namibia, pp. 89-91.

Dawson J.B. (1962) Basutoland kimberlites. Bulletin of the Geological Society of America, Vol. 73, No. 5, pp. 545-560.

De Beers issuing new deferred shares to acquire all the shares of Premier (1923) Mining Magazine, Vol. 28, No. 2 (February), p. 70.

de Magnée I (1947) Présence de kimberlite dans la zone diaman- tifòre de Bakwanga (Kasai, Congo Belge). Bulletin de la Société Belge de Géologie, Vol. 56, No. 3, pp. 97-108.

Diamonds are trumps \{1867\} Cape Argus, Apri1 18, p. 1; as reported in Robertson, 1974, p. 43.

Diamonds found near Mahash on the Lebombo Range, east of Swaziland (1895) South African Mining Journal, Vol. 4, January 12, pp. 299-300.

Diamonds mined off the sea bed (1962) Mining Magazine, Vol. 107, No. 1 (January), p. 40.

Diamond mining (1867) Colesberg Advertiser and Northern Frontier Gazette, July 16, p. 1.

Dickinson J.Y. (1965) The Book of Diamonds. Avenel Books, New York.

Draper D. (1905) The earliest discoveries of dianonds in the Cape Colony and the Transvaal. Engineering and Mining Journal, Vol. 79, pp. 612-613.

Dunn E.J. (1871) Notes on the Diamond-Fields. Saul Solonon \& Co., Cape Town, South Africa, 20 pp.

Een Kaapsche diamant (A Cape diamond) (1867) Het Volksblad, April 30.

Emanuel H. (1865\} Dianonds and Precious Stones. John Camden Hotten, London, $266 \mathrm{pp}$.

Finsch Diamonds (PTY) Ltd. acquired by De Becrs (1963) Mining Magazine, Vol. 108, No. 6 (Junc), p. 321.

Further evidence has been found of the presence of large diamonds at the River Ranch mine (1994) Engineering and Mining Joumal, Vol. 195, No. 1, p. 14.

Gerucht over een diamant gevonden langs de Oranje Rivier [Rumor about a diamond found along the Orange River] [1867) Het Volksblad, April 18.

Gordon C. \{1995\} Angola: A major producer by 2000? Diamond International, May/June, pp. 6I-66.

Government intends to work the Alexander Bay deposits (1928) Mining Magazine, Vol. 38, No. 2 (February), p. 134.

Grasfontein diamond rush (1927) Mining Magazine, Vol. 36, No. 4 (Aprit\}, p. 222.

Greenhalgh P. (1985) West African Diamonds 1919-1983: An Economic History. Manchester University Press, Manchester, England, $306 \mathrm{pp}$.

Gregory J.R. (1868) Diamonds from the Cape of Good Hope. Geological Maguzine, Vol. 5, pp. 561-568.

Gurney J.J., Levinson A.A., Smith H.S. (1991) Marine mining of diamonds off the West Coast of Southern Africa. Gems (b) Gemology, Vol. 27, No. 4, pp. 206-219.

Hallam C.D. (1964) The geology of the coastal diamond deposits of Southem Africa. In S.H. Haughton, Ed., The Geology of Some Ore Deposits in Southern Africa, Geological Society of South Africa, Johannesburg, pp, 671-728.

Harger H.S. (1911) The Bloemhof and Mooifontein diamond digging. South African Mining Joumal, Vol. 9, Part 2, November 18 (pp. 363-364), November 25 (pp. 401-402), and December 2 (p. 440 아.

Hargraves E.H. (1851) Extract from printed papers relative to geological surveys, etc.: Further papers relative to the discovery of gold in Australia. Discovery of Gold, Australia, George E. Eyre and William Spottiswoode, London.

Hawthome J.B, Carrington A.J., Clement C.R, Skinner E.M.W. (1979) Geology of the Dokolwayo kimberlite and associated palaeo-alluvial cleposits. In F.R. Boyd and H.O.A. Meyer, Eds, Kimberlites, Diatremes, and Diamonds: Their Geology, Petrology, and Geochemistry, Vol. 1, Proceedings of the Second International Kimberlite Conference, American Geophysical Union, Washington, DC, pp. 59-70.

Helme N. (1974) Thomas Major Cullinan, a Biography. McGrawHill, Johannesburg, South Africa, $271 \mathrm{pp}$.

Higson G.S. (1870) Diamonds and gold at the Cape. Joumal of the Society of Arts (Loidon), Vol. 18, July 29, pp. 759-760.

Hollaway J. and Associates (1995) Zimbabwe. Mining Annual Review 1995, The Mining Joumal, London, pp. 138-140. 
How diamonds were discovered in the Belgian Congo (1925) Engineering and Mining Journal, Vol, 119, No. 2, p. 43.

How the Orapa pipe was discovered (1971) Diamond News and S.A. Jeweller, February, pp. 7-10.

Hübner A. \{1871) Geognostische Skizzen von den SüdAfrikanischen Diamanten-Districten. Petermann (Geografische) Mittheilungen, Vol. 17, No. 3, pp. 81-87.

Jacobs' diamond was not the first (1867) Colesberg Advertiser and Northern Frontier Gazette, June 4.

Janse A.J.A. (1975) Kimberlite and related rocks from the Nama Plateau of South-West Africa. Physics and Chemistry of the Earth, Vol. 9, pp. 81-94.

Jeffries D. (1750) A Treatise on Diamonds and Pearls. London.

Jones A. (1982) Falconbridge plans De Beers link for diamond search in Africa. Northern Miner, Vol. 68, No. 34 (October 28), pp. $1,19$.

Jourdan P. (1990) The Minerals Industry of Angola. University of Zimbabwe Institute of Mining Research Report No. 116, pp. 911

Kaiser E. (1926) Die Diamantwüste Südwestafrikas, Vols. 1-2. Dietrich Reimer, Berlin.

Koingnaas alluvial diamond mine opening (1978) Mining Magazine, Vol. 139, No. 4/October\}, pp.357-358.

Krashes L.S. (1993) Harry Winston, The Ultimate leweler. Harry Winston Inc., New York.

Kunz G.F. (1885) Precious stones. In Mineral Resources of the United States, Calendar Years 1883-1884, U.S. Department of the Interior, Washington, DC, pp. 723-782.

Kunz G.F. (1892) Gems and Precious Stones of North America, 2nd ed. (Reprinted in 1967 by Dover Publications, New York, $367 \mathrm{pp}$.)

Kunz G.F. (1929) Precious and semi-precious stones. In G.A. Rousch, Ed., The Mineral Industry: Its Statistics, Technology and Trade duing 1928, Vol. 37. McGraw Hill Book Co., New York, pp. 512-537.

Legrand J., Ed. \{1984\} Diamonds, Myth, Magic and Reality, rev. ed. Bonanza Books, New York, 287 pp.

Lehman O. (1955) Look Beyond the Wind: The Life of Dr. Hans Merensky. Howard Timmins, Cape Town, South Africa, 183 pp.

Lengthy wait for weightier diamonds in Lesotho mountains $\{1978\}$ Indiaqua, No. 18, pp. 11-18.

Lenzen G. (1970) The History of Diamond Production and the Diamond Trade. Barrie and Jenkins, London, $230 \mathrm{pp}$.

Levinson O. (1983) Diamonds in the Desert. Tafelberg Publishers, Cape Town, South Africa, $172 \mathrm{pp}$.

Liddicoat R.T., Ed. (1993) The GIA Diamond Dictionary, 3rd ed. Gemological Institute of America, Santa Monica, CA.

Macgregor A.M. (1921) The geology of the diamond-bearing gravels of the Somabula forest (with notes by A.E.V. Zealley). Bulletin of the Southern Rhodesian Geological Survey No. 8, pp. 7-38.

Matthews J.W. \{1878\} Incwadi Yami, or Twenty years' Personal Experience in South Africa. Rogers \& Sherwood, New York, $542 \mathrm{pp}$.

Mennell F.P. (1906) Somabula diamond field of Rhodesia. Geological Magazine, Decade 5, Vol. 3, No. 508, pp. 459-462.

Mennell F.P. (1908) Note on the Rhodesian Diamond Fields. Transactions of the Geological Society of South Africa, Vol. 11, pp. 43-44.

Merensky H. (1904) Technical report on the Premier mine. South African Mining Journal, Vol. 2, Part 2 (September 10), pp. 582-584

Merensky H. (1909) The Diamond Deposits of Lüderitzland, German South-West Africa. Transactions of the Geological Society of South Africa, Vol. 12, pp. 13-23.

Meyer H.O.A. (1991) Marine diamonds off southern Africa. Diamond International, March/April, pp. 49-58.

Middleton J.L. (1932) Diamonds in Equatorial Africa. Engineering and Mining lournal, Vol. 133, No. 5, P. 285.
Mining Annual Review 1995 (1995) The Mining Joumal, London.

Molengraaff G.A.F. (1895) Über ein Vorkommen von Diamanten in dem Bebiete der kohlenführenden Formation bei Driekop im Oranje-Freistaat (About the occurrence of diamonds in the area of the coal-bearing formation near Driekop in the Orange Free State). Nenes Jahrbuch für Mineralogie, Band 1894/95, pp. $277-283$.

Molengraaff G.A.F. (1897) Diamond at Rietfontein. Transactions of the Geological Society of South Africa, Vol. 3, pp. 122-123.

Molengraaff G.A.F. \{1905) The Cullinan diamond. Transactions of the Institute of Mining Engineers, Vol. 24, pp. 507-509.

Murray L.G., Joynt R.H., O'Shea D.O'C., Foster R.W., Kleinjan L. (1970) The geological environment of some diamond deposits off the coast of South West Africa, Report no. 70/13. In F.M. Delaney, Ed., The Geology of the East Atlantic Continental Margin, Natural Environment Research Council, Institute of Geological Sciences, Her Majesty's Stationery Office, London, pp. 119-141.

Murray R.W. (1873) The diamond-field keepsake for 1873. Saul Solomon \& Co., Cape Town, South Africa (facsimile reprint by the Historical Society, Kimberley, South Africa, 1979|, 38 pp.

Namibia: De Beers Centenary has signed an agreement with the Namibian government reconstituting CDM as Namdeb Diamond Corp. (1995) Engineering and Mining Journal, Vol. 196, No. 8, p. 20.

Namibia: The government is acquiring $50 \%$ of De Beers Centenary AG's diamond mine (1995) Engineering and Mining Journal, Vol. 196, No. 1, p. 13.

Nelly Jacobs, the little diamond finder (1867) Colesberg Advertiser and Northern Frontier Gazette, July 30, p. 1.

Nixon P.H., von Knorring O., Rooke J.M. (1963) Kimberlites and associated inclusions of Basutoland: A mineralogical and geochemical study. American Mineralogist, Vol. 48, No. 9/10, pp. 1090-1132.

Noble J. (1874) The diamond fields of South Africa. Temple Bar, Vol. 4l, pp. 385-400.

Orapa opening marks 17 years work (1972) Diamond News and S.A. Jeweller, July, pp. 17-23.

Paterson J. (1873) On a visit to the diamond fields of South Africa. Proceedings of the Geological Association, Vol. 3, pp. 70-80.

Polinard E. (1929) Les diamants translucides et opaques des gisements de la Bushimaie. Annales de la Société Géologique de Belgique, Vol. 52, pp. Cl79-Cl 86.

Precious stone at the Cape of Good Hope (1867) Journal of the Society of Arts, Vol. 15, October 4, p. 703.

The Premier mine, the world's biggest diamond mine (1903) South African Mines, Commerce and Industry, Vol. 1, Part 1 (June 27), pp. 344-346.

Premier (Transvaal) Mining Company-washing results (1903) African World, Vol. 2, February 14, p. 11

Real F. (1958) Sur les roches kimberlitiques de la Lunda (Angola). Boletim de Musen e Laboratoria Minerais e Geologico. Faculdad Ciencias, Universidad de Lisboa, Series 7, No. 26 pp. $220-253$.

Reunert T. (1893) Diamonds and Gold in South Africa. J.C. Juta \& Co., Cape Town, South Africa, 242 pp.

Reuning E. (1928) The discovery of the Namaqualand diamonds. Mining and Industrial Magazine of South Africa, Vol. 7, pp. $51-55,87-91,141-143,219-221$, and 265-267.

Robertson M. (1974) Diamond Fever, South African History 1866-9, from Primary Sources. Oxford University Press, Cape Town, South Africa, $250 \mathrm{pp}$.

Rose G. (1837) Mineralogisch-geognostische Reise nach dem Ural, dem Altai und dem Kaspischen Meere, Erster Zweiter Band, Reise nach dem nördlichen Ural und dem Altai. Sanderschen Buchhandlung (C.W. Eichhoff], Berlin, 641 pp.

Roux J. (1994) Canadians lead revival in the C.A.R. Diamond International, May/June, pp. 91-92, 95-96.

Sarmento J. de C. $\{1735\}$ Historical accounts of the discovery of 
gold and diamonds in Minas Gerais. Materia Medica-PhysicoHistorio-Mechanica, Regno Mineral 1, London, pp. 149-154.

Scheibe R. (1906) Der Blue Ground des Deutsch Südwest Afrika in Vergleich mit dem des englischen Süd Afrikas (The blue ground of German South West Africa compared to that of English South Africa). Programm der königlichen Bergakademie zu Berlin, Feister'schen Buchdruckerei, Berlin, I8 pp.

Shepard C.U. (1846) On three new mineral species from Arkansas, and the discovery of diamond in North Carolina. American Journal of Science, 2nd ser., Vol. 22, pp. 249-254.

Sinkankas J. (1976) Gemstones of North Annerica, Vol. 2. Van Nostrand Reinhold, New York.

The Sterkfontein diamond diggrings (1923) South African Mining and Engineering Joumal, Vol. 35, No. 1648, pp. 152-153.

Steytler J.G. ( 1870 ) Letter, dated July 23, reporting the discovery of diamonds on Jagersfontein. In The Emigrant's Guide, the Diamond-Fields of South Africa, Saul Solomon, Cape Town, South Africa, p. 18.

Stockley G.M. (1947) Report on the Geology of Basutoland. Government Printer, Maseru, Lesotho, $114 \mathrm{pp}$.

Tennant J. (1870) South African diamonds. Joumnal of the Society of Atts (London), Vol. 19, November 25, pp. 15-19.

Twenty diamonds found so far along the banks of the Orange River, see map (1868) Cape Argus, October 31

Wagner P.A. (1914) The Dianond Fields of Southern Africa. The Transvaal Leader, Johannesburg, South Africa (reprinted in 1971 by C. Struik, Cape Town, South Africa, 355 pp.).

Wagner P.A., Merensky H. (1928) The diamond deposits on the coast of Little Namaqualand. Transactions of the Geological Society of South Africa, Vol. 31, pp. 1-4l.

Wayland E.J. (I949) Minerals in the Bechuanaland Protectorate.
Unpublished report, Bechuanaland Geological Survey Department.

Weakley J.R. (1869) The diamond discovery in South Africa (a collection of articles and original correspondence from various colonial joumals and original remarks refuting erroneous statements by H. Emanuel and J.R. Gregory|. Colesberg Advertiser, Colesberg, South Africa, $35 \mathrm{pp}$.

Webster R. (1975) Gems: Their Sources, Descriptions and Identification, 3rd ed. Butterworth \& Co., London.

Williams G.F. (1905) The Diamond Mines of South Africa. Macmillan Co., New York

Williams A.F. (1930) Diamond bearing gravels of the Union of South Africa. In Proceedings of the Third (Triennial) Enpire Mining and Metallurgical Congress, South Africa, March 24 May 8, Part 3, Paper 2, $169 \mathrm{pp}$.

Williams A.F. (1932) The Genesis of the Diamond, Vols. 1-2 Emest Benn, London, $636 \mathrm{pp}$.

Williams G.F. (1886) The diamond mines of South Africa. Transactions of the Arnerican Institute of Mining Engineers, Vol. 15, pp. 392-417.

Williams G.F. (1905) The Diamond Mines of South Africa, Vols. I-2. B.F. Buck \& Co., New York.

Wilson A.N. (1972) Spectacular finds in the Orange River terraces. In A. N. Wilson, Diamond International No. 2, Diamond International (Pty.) Ltd., Johannesburg, pp. 53-54.

The wonderful South African diamond (I 867) Colesberg Advertiser and Northern Frontier Gazette, April 9.

Young prospector carved niche for himself in history (1969) Diamond News and S.A. Jeweller, September, pp. 18-19.

Zimbabwe diamond hunt expands (1994) Diamond International, No. 29, May/June, pp. 23-24

\section{IN RESPONSE TO POPULAR DEMAND...}

\section{GIA PRESENTS}

INSURANCE

REPLACEMENT

APPRAISAL

Learn-At-Home Course \#52

GIA is proud to bring you one of the most eagerly awaited Learn-

At-Home courses in recent memory. Now you can get the training you need to properly prepare insurance replacement appraisals.

For more information or to enroll

Call (800) 421-7250 ext. 292

Outside the U.S.

(310) 829-2991 ext. 292

Fax (310) 453-7674

Gra Learn-At-Home

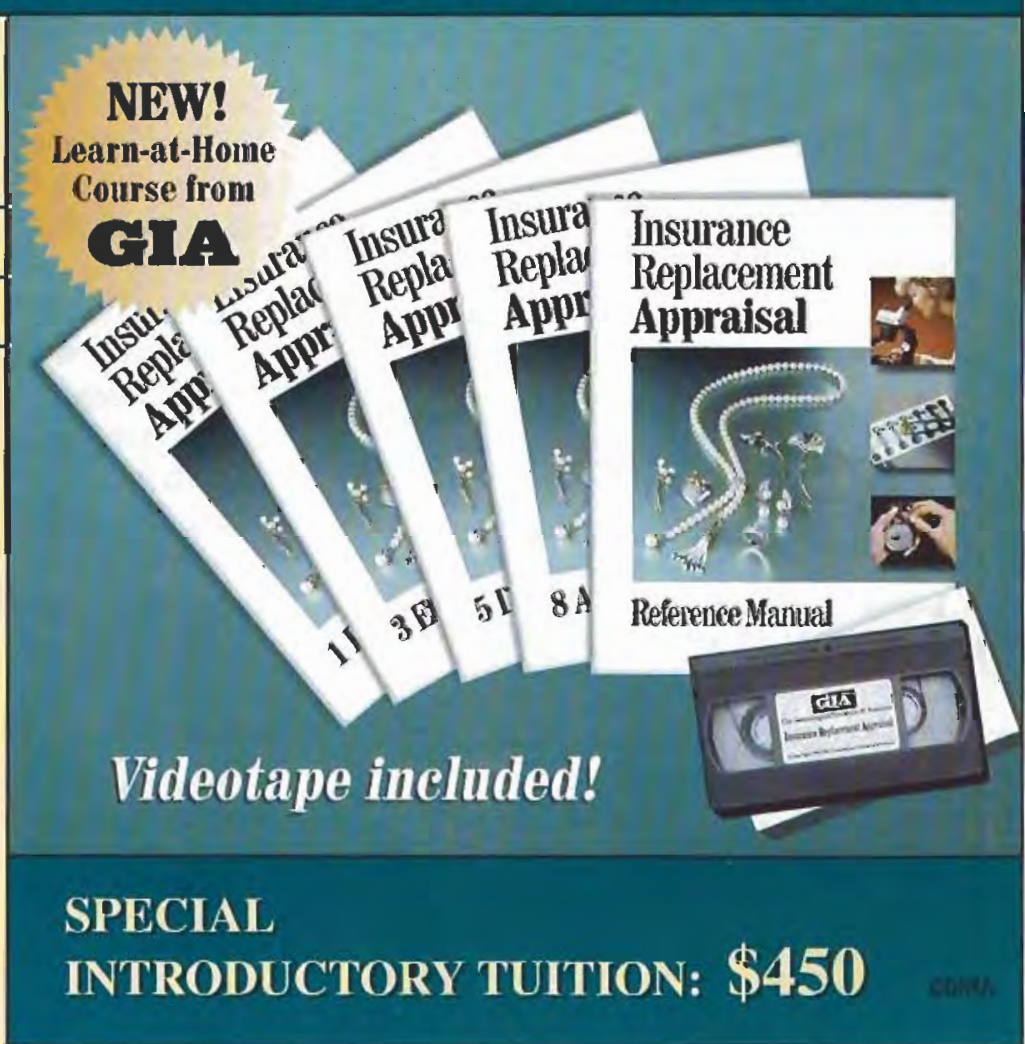

